\title{
Coloured nectar: distribution, ecology, and evolution of an enigmatic floral trait
}

\author{
Hansen, D M ; Olesen, J M ; Mione, T ; Johnson, S D ; Müller, C B
}

\begin{abstract}
While coloured nectar has been known to science at least since 1785, it has only recently received focused scientific attention. However, information about this rare floral trait is scattered and hard to find. Here, we document coloured nectar in 67 taxa worldwide, with a wide taxonomical and geographical distribution. We summarise what is currently known about coloured nectar in each of the lineages where it occurs. The most common nectar colours are in the spectrum from yellow to red, but also brown, black, green, and blue colours are found. Colour intensity of the nectar varies, sometimes even within one taxa, as does the level of contrast between flower petals and nectar. Coloured nectar has evolved independently throughout the angiosperms at least 15 times at the level of family, and is in many cases correlated with one or more of three parameters: (1) vertebrate pollination, known or hypothesised, (2) insularity - many species are from islands or insular mainland habitats, and (3) altitude - many species are found at relatively high altitudes. We discuss the evolution and speculate on possible ecological functions of coloured nectar. Apart from being a non-functional, perhaps pleiotropic, trait, we present several hypotheses on possible ecological functions of coloured nectar. Firstly, for some plant species it can be interpreted as an honest signal, leading to high pollination efficiency. Secondly, it can function as a deterrent against nectar-thieves or inefficient pollinators, thus acting as a floral filter. Thirdly, nectar colour-pigments can have anti-microbial qualities that may protect the nectar in long-lived flowers. Neither of these possibilities are mutually exclusive. Recent studies have provided experimental evidence for the first two hypotheses, and we suggest promising avenues for future research into this little-known floral trait.
\end{abstract}

DOI: https://doi.org/10.1111/j.1469-185X.2006.00005.x

Posted at the Zurich Open Repository and Archive, University of Zurich ZORA URL: https://doi.org/10.5167/uzh-2077

Journal Article

Originally published at:

Hansen, D M; Olesen, J M; Mione, T; Johnson, S D; Müller, C B (2007). Coloured nectar: distribution, ecology, and evolution of an enigmatic floral trait. Biological Reviews, 82(1):83-111.

DOI: https://doi.org/10.1111/j.1469-185X.2006.00005.x 


\title{
Coloured nectar: distribution, ecology, and evolution of an enigmatic floral trait
}

\author{
Dennis M. Hansen ${ }^{1 *}$, Jens M. Olesen², Thomas Mione ${ }^{3}$, Steven D. Johnson ${ }^{4}$ and \\ Christine B. Müller ${ }^{1}$ \\ ${ }^{1}$ Institute of Environmental Sciences, University of Zurich, Winterthurerstrasse 190, 8057 Zurich, Switzerland \\ ${ }^{2}$ Department of Ecology $\&$ Genetics, University of Aarhus, Block 540, Ny Munkegade, 8000 Aarhus C, Denmark \\ ${ }^{3}$ Biology Department, Copernicus Hall, Central Connecticut State University, New Britain, CT 06050-4010, USA \\ ${ }^{4}$ School of Biological and Conservation Sciences, University of KwaZulu-Natal, P. Bag X01 Scottsville, Pietermaritzburg 3209, South Africa
}

(Received 17 March 2006; revised 25 October 2006; accepted 6 November 2006)

\begin{abstract}
While coloured nectar has been known to science at least since 1785, it has only recently received focused scientific attention. However, information about this rare floral trait is scattered and hard to find. Here, we document coloured nectar in 67 taxa worldwide, with a wide taxonomical and geographical distribution. We summarise what is currently known about coloured nectar in each of the lineages where it occurs. The most common nectar colours are in the spectrum from yellow to red, but also brown, black, green, and blue colours are found. Colour intensity of the nectar varies, sometimes even within one taxa, as does the level of contrast between flower petals and nectar. Coloured nectar has evolved independently throughout the angiosperms at least 15 times at the level of family, and is in many cases correlated with one or more of three parameters: (1) vertebrate pollination, known or hypothesised, (2) insularity - many species are from islands or insular mainland habitats, and (3) altitude - many species are found at relatively high altitudes. We discuss the evolution and speculate on possible ecological functions of coloured nectar. Apart from being a non-functional, perhaps pleiotropic, trait, we present several hypotheses on possible ecological functions of coloured nectar. Firstly, for some plant species it can be interpreted as an honest signal, leading to high pollination efficiency. Secondly, it can function as a deterrent against nectar-thieves or inefficient pollinators, thus acting as a floral filter. Thirdly, nectar colour-pigments can have anti-microbial qualities that may protect the nectar in long-lived flowers. Neither of these possibilities are mutually exclusive. Recent studies have provided experimental evidence for the first two hypotheses, and we suggest promising avenues for future research into this little-known floral trait.
\end{abstract}

Key words: floral trait, nectar properties, mutualism, pollination biology, pollinator attraction, signalling theory, honest signal, floral filter.

\section{GONTENTS}

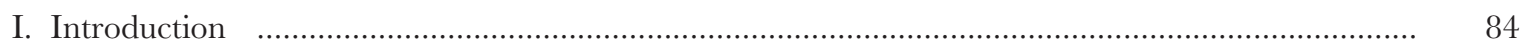

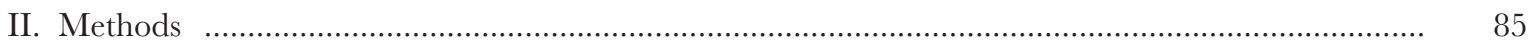

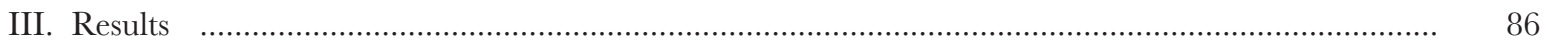

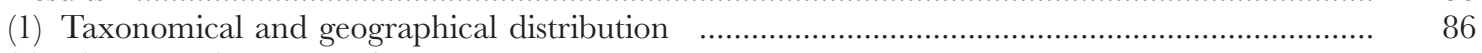

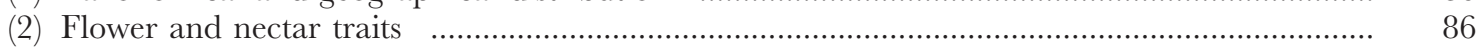

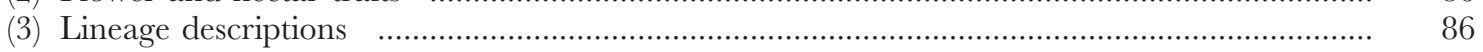

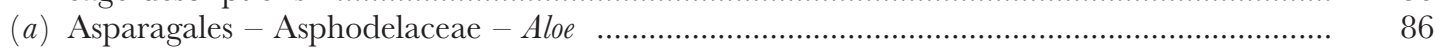

(b) Asparagales - Hemerocallidaceae - Phormium ………..................................................... 92

(c) Asterales - Campanulaceae - Nesocodon ……................................................................... 93

*Address for correspondence: E-mail: dhansen@uwinst.unizh.ch 


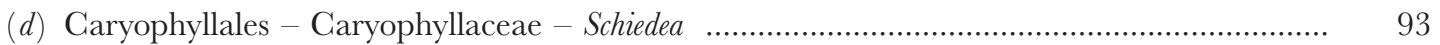

(e) Ericales - Marcgraviaceae - Schwartzia …………............................................................ 93

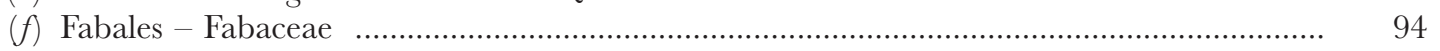

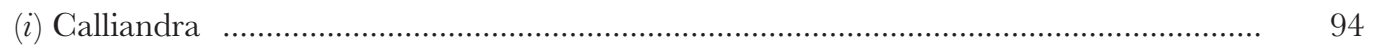

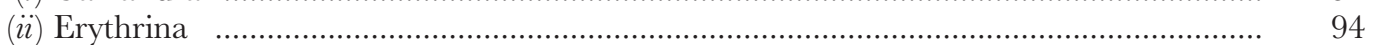

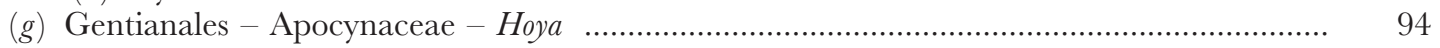

(h) Geraniales - Melianthaceae - Melianthus ………............................................................. 94

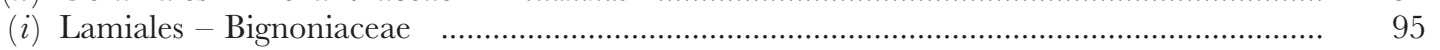

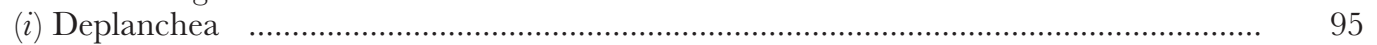

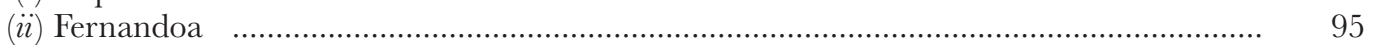

(j) Lamiales - Lamiaceae - Leucosceptrum ………….......................................................... 95

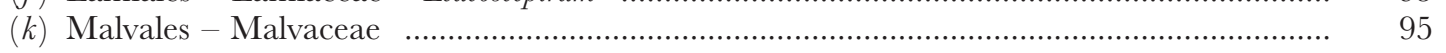

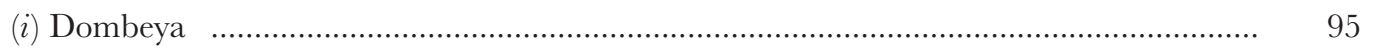

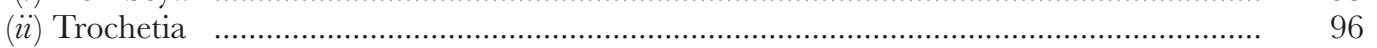

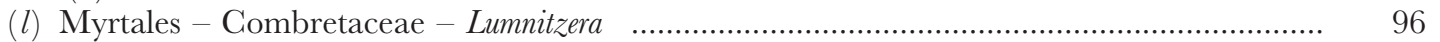

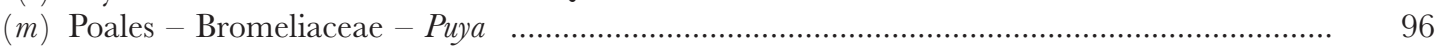

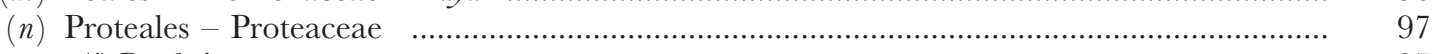

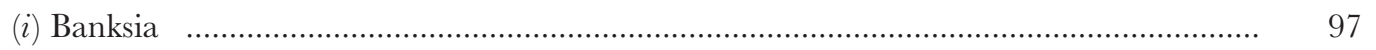

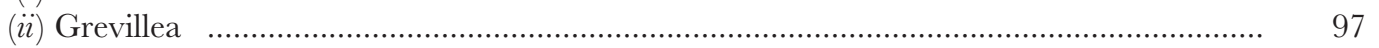

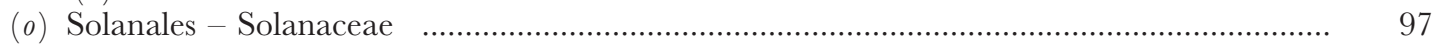

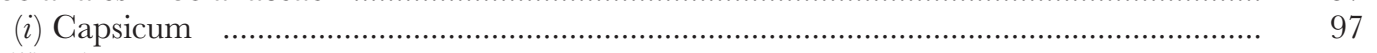

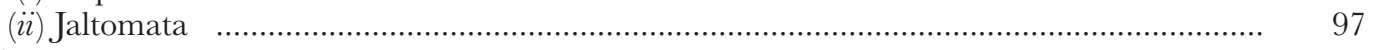

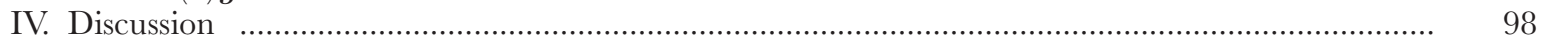

(1) Environmental and ecological correlates of coloured nectar …............................................ 98

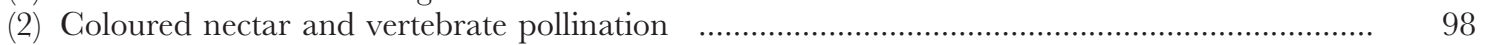

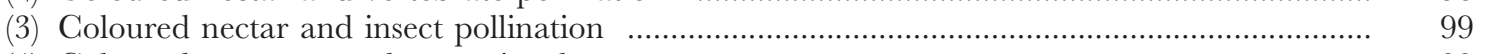

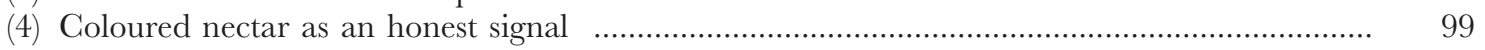

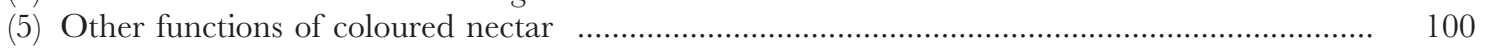

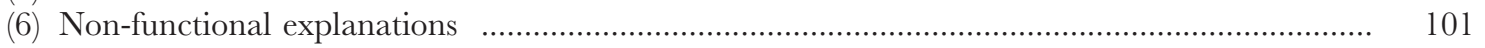

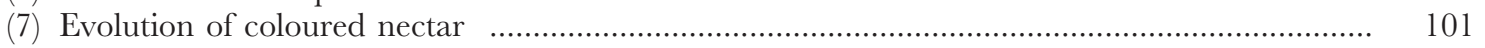

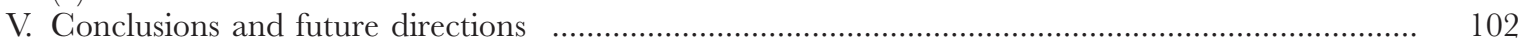

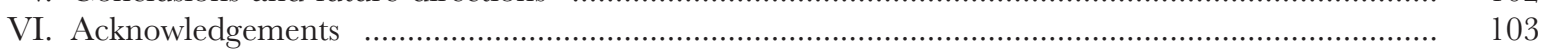

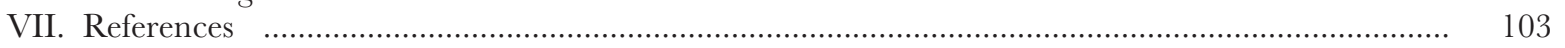

IX. References not listed in main manuscript: ……................................................................ 110

\section{INTRODUGTION}

Ever since Sprengel's landmark publication in 1793, researchers have tried to understand how floral traits affect interactions with pollinators, and vice versa. One floral trait that has received much attention is nectar, the main 'currency' of many pollination interactions. Analytical research on nectar properties has focused on the composition of sugars (Percival, 1961; Baker \& Baker, 1983; Baker, Baker \& Hodges, 1998) and amino acids (Baker \& Baker, 1973, 1986; Gottsberger, Schrauwen \& Linskens, 1984). Lately, more specific ecological traits and functions of nectar have been studied; e.g. taste (Gardener \& Gillman, 2002), toxicity (Ehlers \& Olesen, 1997; Adler, 2000), and scent (Raguso, 2004b), including how these traits interact with the physiology and behaviour of flowervisiting animals. The general conclusions in these studies are that little is known about 'nectar ecology'. Herein we review the occurrence of a particularly enigmatic nectar trait, colour, and speculate about its ecological functional significance and evolution.

A divine liquid in mythology, red nectar is known from antiquity. In the Illiad, Homer describes the actions of the goddess Thetis as she preserves the body of the dead warrior Patroclus: "she then dropped ambrosia and red nectar into the wounds of Patroclus, that his body might suffer no change." (Book XIX, verses 37-39). In modern science, coloured nectar has a long history as well. The first reference to coloured nectar is found in Dissertatio de Aloe (Hesselius, 1785), where the description of Aloe spicata includes the line, "Corollae repletae sunt succo melleo purpurascente", clearly referring to the corolla being replete with sweet, dark-red nectar. The most eloquent early description of coloured nectar is found in one of the oldest volumes of Curtis's Botanical Magazine (1795, Volume 9, Plate 301), where the description of Melianthus minor ( $=$ M. comosus) (Melianthaceae) states: "There are few flowers that do not secrete from some kind of a glandular substance, honey, or 
nectar, to a greater or smaller amount; in those of the present genus, this liquid is particularly abundant ... and is of a dark brown colour, an unusual phenomenon". Furthermore, the accompanying plate shows this detail in such quality, that it is possible to see the dark nectar through the pale green, semi-transparent sepals, much like it can be seen in the wild (Fig. 1). This species was first described only one year earlier, but the diagnosis does not mention the coloured nectar, or even the abundance of nectar (Vahl, 1794). This points to the crux of the matter in our current understanding of coloured nectar: for the majority of taxa with coloured nectar, the taxonomical description does not mention the colouration of the nectar. Another early example of this is Faltomata aspera (Solanaceae) of Peru. Ruiz \& Pavón (1799) described the pale cream-coloured corolla of $\mathcal{F}$. aspera, as "violet in the centre". However, long reflected in its local name, lágrima de la virgen, or 'tear of the virgin', the red nectar of this plant was not described by botanists until Bitter (1921) wrote about the "copious production of a blood-red juice from glands at the bottom of the corolla between the anthers". In the case of Melianthus and Aloe, where coloured nectar has long been known, it has not been reported in mainstream ecological or botanical journals, but only in taxonomical descriptions and studies. In most other lineages, the coloured nectar is not even mentioned in the taxonomical descriptions or studies of the plants.

Given its visual impact, it is surprising that so little is known about coloured nectar. The almost complete omission of reference to nectar colour in the taxonomical literature has limited our knowledge of the geographical and taxonomical distribution of coloured nectar, and has made studies of its possible ecological function and evolution difficult. The main reason is without doubt that the original descriptions were based on herbarium material. Here, of course, the nectar has long dried out, leaving at most only discoloured marks that are difficult to interpret. Marloth (1925), for example, simply discounted the dark stains of nectar on a dry herbarium specimen of $A$. spicata as a reaction between clear nectar and the filaments or the paper used in pressing the plant - a mistake that was later pointed out by Glen \& Hardy (1995). To summarise, in all

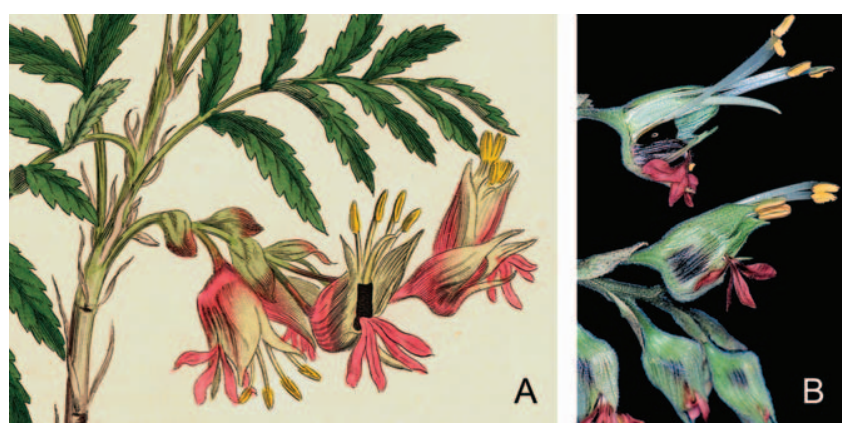

Fig. 1. Melianthus minor flowers. (A) Part of an illustration in Curtis's Botanical Magazine (1795, Volume 9, Plate 301). (B) Photograph of flowers of a botanical garden plant. Note how the black nectar is clearly visible through the pale, semitranslucent sepals in both pictures. Photograph by W. Barthlott. taxa coloured nectar was only mentioned in the literature after investigation of living plants.

Nesocodon mauritianus (Campanulaceae) was the first species with coloured nectar for which the ecology and nectar-chemistry was studied in detail (Olesen et al., 1998). The species was discovered on the island of Mauritius in 1976 , but there was no mention of the blood-red colour of the nectar in the taxonomical description (Richardson, 1979). Later, after studying $\mathcal{N}$. mauritianus plants in cultivation, Wyse Jackson (1990) was the first to mention the red nectar of this species. Olesen et al. (1998) also reported the presence of coloured nectar in two Mauritian Trochetia (Malvaceae) species, T. blackburniana and T. boutoniana, and stated that - to their knowledge - these plants, along with $\mathcal{N}$. mauritianus, were the only ones in the world with coloured nectar. From our detailed research for this review it is now obvious that this is not true. However, information on coloured nectar is hard to find in the mainstream scientific literature, and is often known only from grey literature or observations. Our study reviews the occurrence of and knowledge on coloured nectar in flowering plants. Specifically, we aim to (1) document and investigate the geographical and taxonomical distribution of coloured nectar in flowering plants, (2) summarise the current knowledge about species with coloured nectar and the lineages in which they occur, (3) investigate possible environmental and ecological correlates of coloured nectar, and (4) discuss its possible ecological functions and its evolution.

\section{METHODS}

We here define coloured nectar as a floral sugary secretion that contains one or more pigments or coloured substances that are apparently produced and secreted by the plants. We include only species with nectar colours in the spectrum visible to humans. One study has documented ultravioletfluorescent nectar in several species (Thorp et al., 1975). However, there have been no further studies of this trait, and we have not included species with known UVfluorescent nectar in our study.

The idiosyncratic literature on coloured nectar precluded any attempt to obtain data in a standardised and methodological way. We conducted a thorough search of the literature, using library and scientific databases, web pages, scientific publications, and regional and national floras. In web-based databases and search engines we used specific queries, searching for 'nectar' in combination with each of the following words 'colour, coloured, dark, black, red, brown, yellow, orange, green, blue, purple' in English (US and UK), Spanish, Portuguese, French, German and Danish. Furthermore, we contacted many pollination biologists, plant biologists and taxonomists, attempting to cover a broad geographical and taxonomical range, and inquired about observations of coloured nectar. When coloured nectar was confirmed for a species, we also acquired information from the literature about related species, and by contacting researchers studying related species within the same lineage. We also included our personal observations on taxa with coloured nectar. We compiled a database with data on growth form, geographical 
and taxonomical distribution and altitudinal range; on floral traits, including size, colour and morphology; and on nectar traits, including volume, concentration and sugar composition. Then we examined this database, aiming to identify any potential correlations that would help us formulate hypotheses on its possible ecological functions and evolution of coloured nectar. Furthermore, we gathered information on the different lineages with coloured nectar and their closest relatives to summarise our current knowledge within each lineage. If available, we included ecological and evolutionary information in our summary.

\section{RESULTS}

\section{(1) Taxonomical and geographical distribution}

In total, we were able to document the presence of coloured nectar in 68 taxa from 20 genera in 15 families (Table 1; Fig. 2). These taxa occur in tropical and subtropical regions, with a wide geographical distribution (Table 1). We found that coloured nectar occurs in at least 13 angiosperm orders, covering widely separated branches of the phylogenetic tree. Coloured nectar is found in both monocots and eudicots, but not in the magnoliids or paleoherbs (Fig. 3).

\section{(2) Flower and nectar traits}

The flowers of species with coloured nectar show large variation in nectar colours (Table 1, Fig. 2). The colours of nectar can be divided into the following broad categories (using the 'darkest' recorded nectar colour for a taxon in Table 1; relative frequency in parenthesis): yellow (15 taxa; $22.1 \%$ ), amber - orange (six taxa; 8.8\%), red (17 taxa; $25 \%$ ), brown (14 taxa; 20.6\%), green (five taxa; $7.4 \%$ ), blue (two taxa; 2.9\%) and black (nine taxa; 13.2\%). Thus, we find that $55.9 \%$ of the taxa have nectar colours in the range from yellow to red, and most of those with darker colours (brown or black) are very dark hues of red. Only in Schiedea does the black colouration seem to originate from grey hues (S. G. Weller, personal communication). The green colours of the nectar in some Banksia species are also clearly outside the 'red' group, even though the nectar in young flowers of these species has a yellow colouration (Markey \& Lamont, 1995). Puya alpestris and Schwartzia brasiliensis are the only known species with blue or blue-red nectar. The level of contrast between the flower petals and the nectar also varies (Table 1). In most species, the nectar contrasts well against the petals in the human visible spectrum, but even in plants with overall petal colours similar to the nectar colour, the nectar often still contrasts due to being present on lighter parts of the corolla (see Fig. 2, and Section IV.4).

Species with coloured nectar also vary widely in growth form and floral morphology, with plants ranging from vines and small shrubs to large trees, and having from radially symmetrical to strongly zygomorphic flowers in many different colours (Table 1; Fig. 2). However, most flowers are open and easily accessible to visitors (e.g. Hoya, Fig. 2B,C; Trochetia Fig. 2G; Aloe Fig. 2D, J; Capsicum Fig. 2P), or if more closed or tubular, the nectar can often be seen from the outside at a distance, through a pale or semi-translucent calyx or corolla (in some Melianthus species, Fig. 1; and in some faltomata species, Fig. 2K). For nectar traits, we have only found information for a subset of the plants with coloured nectar (Table 2). From this it is clear, however, that most produce relatively large amounts of nectar, forming visible drops in the flowers. Furthermore, most of the species for which we have information have sugars that are hexose-dominated (Table 2).

\section{(3) Lineage descriptions}

In the following we summarise and discuss our current knowledge of coloured nectar in each lineage, with an emphasis on pollination ecology if data are available.

(a) Asparagales - Asphodelaceae - Aloe

Aloe is a large genus with some 365-400 species, native to Africa, the Arabian Peninsula and Madagascar (Mabberley, 1997; Viljoen, van Wyk \& van Heerden, 1998). Growth forms vary from dwarf rosettes to trees of more than $15 \mathrm{~m}$ in height. Most Aloe species have large inflorescences with long, slender, pendulous and tubular flowers (van Wyk \& Smith, 1996). However, one small section, Anguialoe, comprises four species with very dense racemes or spikes that carry short, sessile and campanulate flowers (Reynolds, 1940; Glen \& Hardy, 1995). Coloured nectar is found in all four species currently recognised within Anguialoe, albeit at varying levels of colour intensity (Fig. 2D, J; Table 1). Contrary to most other lineages where coloured nectar occurs, it has been known for a long time in Aloe. Hesselius' (1785) treatment of the genus contains the first scientific reference to coloured nectar that we have been able to find (see Section I), and it has been mentioned regularly in the scientific literature since then. For example, Pole Evans (1925) describes the flowers of $A$. sessiliflora (= A. spicata), stating that they "contain drops of very dark nectar", and Groenewald (1938), in his description of $A$. dolomitica ( $=$ A. vryheidensis), makes a note of the dark brown nectar in the flowers. Dyer (1931) mentions the flowers of $A$. sessiliflora being "filled with a reddish nectar", and later he states that the nectar of $A$. vryheidensis "appears almost black in colour" (Dyer, 1941). In the original circumscription of Anguialoe, Reynolds (1940) even used the flowers' "copious supply of dark nectar" as a defining trait for the section. However, clear rather than coloured nectar has been noted in the wild for $A$. alooides (B.-E. van Wyk, personal communication), but in a greenhouse in the National Botanical Garden of Belgium, a plant produced red nectar in 2002 (B. Loison, personal communication). Lastly, the dark nectar is also mentioned in some of the more popular accounts of Aloe species (e.g. Court, 1981; van Wyk \& Smith, 1996). For Aloe section Anguialoe in general, Reynolds (1940) remarked that the nectar seems to be of a lighter colour in young flowers, while it is darker in the oldest flowers. Nicolson \& Nepi (2005) mention the same for the nectar in $A$. castanea flowers. This colour change is due to oxidation of phenolic compounds that impart the dark brown colour to the nectar $(\mathrm{H}$. F. Glen, personal communication; S. D. Johnson, A. Hargreaves \& M. Brown, unpublished data). A recent study has shown that Aloe 
Table 1. Plant taxa with coloured nectar; their geographical and altitudinal distribution, growth form, flower morphology, nectar colour and observed flower visitors ('nd' = no data available)

\begin{tabular}{|c|c|c|c|c|c|c|c|c|c|c|}
\hline Order & Family & Species & Distribution & Altitude (masl) & Growth form & Flower form & $\begin{array}{l}\text { Flower size } \\
(\mathrm{mm})^{1}\end{array}$ & Flower colour $^{2}$ & Nectar colour $^{2}$ & $\begin{array}{l}\text { Flower } \\
\text { visitors }{ }^{3}\end{array}$ \\
\hline \multirow[t]{5}{*}{ Asparagales } & \multirow[t]{4}{*}{ Asphodelaceae } & Aloe alooides & South Africa & $1450-2000$ & shrub & campanulate & 9 & yellow & $\begin{array}{l}\text { clear - } \\
\text { red }\end{array}$ & $\mathrm{B}, \mathrm{I}$ \\
\hline & & A. castanea & South Africa & $1400-1700$ & shrub & campanulate & $18-19$ & orange - red & $\begin{array}{l}\text { yellow - } \\
\text { brown }\end{array}$ & $\mathrm{B}, \mathrm{I}$ \\
\hline & & A. vryheidensis & South Africa & $1300-1550$ & shrub & campanulate & 14 & yellow & $\begin{array}{c}\text { dark red - } \\
\text { brown }\end{array}$ & $\mathrm{B}, \mathrm{I}$ \\
\hline & & A. spicata & $\begin{array}{l}\text { South Africa, } \\
\text { Zimbabwe }\end{array}$ & $700-1000$ & shrub & campanulate & $18-20$ & yellow & $\begin{array}{c}\text { dark red - } \\
\text { brown }\end{array}$ & $\mathrm{B}, \mathrm{I}$ \\
\hline & Hemerocallidaceae & Phormium tenax & New Zealand & $0-1000$ & shrub & tubular & $26 \times 7-9$ & orange - red & $\begin{array}{l}\text { clear - } \\
\text { yellow }\end{array}$ & $\mathrm{B}, \mathrm{L}$ \\
\hline Asterales & Campanulaceae & $\begin{array}{l}\text { Nesocodon } \\
\quad \text { mauritianus }\end{array}$ & Mauritius & $5-600$ & subshrub & campanulate & $50 \times 30$ & blue & $\begin{array}{l}\text { orange - } \\
\text { red }\end{array}$ & $\mathrm{B}$ ?, L?, B† \\
\hline \multirow[t]{4}{*}{ Caryophyllales } & \multirow[t]{4}{*}{ Caryophyllaceae } & Schiedea lychnoides & Kaua’i & $1090-1320$ & vine & campanulate & $5,9-12^{4}$ & white $^{5}$ & black & $\mathrm{u}, \mathrm{B}$ ? \\
\hline & & S. obovata & O'ahu & $550-800$ & shrub & campanulate & $7-8.4^{4}$ & white $^{5}$ & black & $\mathrm{u}, \mathrm{B}$ ? \\
\hline & & S. trinerve & O’ahu & $900-1230$ & subshrub & ball-shaped & $6-8^{4}$ & white $^{5}$ & black & $\mathrm{u}, \mathrm{B}$ ? \\
\hline & & S. viscosa & Kaua’i & $820-1150$ & vine & campanulate & $5,6.5-9^{4}$ & white $^{5}$ & black & $\mathrm{u}, \mathrm{B}$ ? \\
\hline Ericales & Marcgraviaceae & $\begin{array}{l}\text { Schwartzia } \\
\quad \text { brasiliensis }\end{array}$ & Brazil & $0-800$ & vine & urceolate $^{6}$ & $10-12 \times 8-10^{6}$ & $\begin{array}{l}\text { dark purple- } \\
\text { brown }^{6}\end{array}$ & blue & $\mathrm{B}, \mathrm{I}$ \\
\hline \multirow[t]{4}{*}{ Fabales } & \multirow[t]{4}{*}{ Fabaceae } & $\begin{array}{l}\text { Calliandra } \\
\text { calothyrsus }\end{array}$ & $\begin{array}{l}\text { S Mexico to } \\
\text { C Panama }\end{array}$ & $0-1800$ & tree & brush-type & $6-8,40-60^{7}$ & green and red $^{8}$ & yellow & M, I, B \\
\hline & & Erythrina caffra & South Africa & nd & tree & zygomorphic & $42-70 \times 27-40$ & red & $\begin{array}{l}\text { clear - } \\
\text { pale brown }\end{array}$ & B \\
\hline & & E. humeana & Southern Africa ${ }^{9}$ & nd & shrub & zygomorphic & $35-50 \times 14-21$ & red & amber & B \\
\hline & & E. zeyheri & South Africa & $1700-1750$ & subshrub & zygomorphic & $2444 \times 14-22$ & red & pale yellow & B \\
\hline \multirow[t]{5}{*}{ Gentianales } & \multirow[t]{5}{*}{ Apocynaceae } & Hoya diversifolia & $\mathrm{Asia}^{10}$ & lowland & vine & rotate & 13 (diameter) & $\begin{array}{l}\text { cream - } \\
\quad \text { pale pink }{ }^{11}\end{array}$ & $\begin{array}{l}\text { amber - } \\
\text { brown }\end{array}$ & $\mathrm{u}$ \\
\hline & & H. excavata & Malaysia & nd & vine & rotate & 13 (diameter) & pink $^{11}$ & brown & $\mathrm{u}$ \\
\hline & & H. kerrï & $\operatorname{Asia}^{10}$ & 390 & vine & rotate & 9-13 (diameter) & $\begin{array}{l}\text { white - } \\
\text { cream }^{11}\end{array}$ & $\begin{array}{l}\text { amber - } \\
\text { brown }\end{array}$ & $\mathrm{u}$ \\
\hline & & H. meliflua & Philippines & lowland & vine & rotate & 15 (diameter) & $\begin{array}{l}\text { pink - } \\
\text { purple }^{11}\end{array}$ & dark red & $\mathrm{u}$ \\
\hline & & H. obovata & $\mathrm{Asia}^{10}$ & nd & vine & rotate & 15 (diameter) & $\begin{array}{l}\text { cream - } \\
\text { pink }^{11}\end{array}$ & brown & $\mathrm{u}$ \\
\hline \multirow[t]{8}{*}{ Geraniales } & \multirow[t]{8}{*}{ Melianthaceae } & $\begin{array}{c}\text { Melianthus } \\
\text { comosus }\end{array}$ & $\begin{array}{l}\text { South Africa, } \\
\text { Namibia }\end{array}$ & $400-2000$ & shrub & zygomorphic & $15-32 \times 10^{12}$ & $\begin{array}{l}\text { green - } \\
\text { pale pink }\end{array}$ & black & $\mathrm{B}, \mathrm{I}$ \\
\hline & & M. dregeanus & South Africa & $600-1800$ & shrub & zygomorphic & $15-20 \times 10^{12}$ & $\operatorname{red}^{13}$ & brown & B \\
\hline & & M. elongatus & South Africa & $0-300$ & shrub & zygomorphic & $15-22 \times 8^{12}$ & green $^{13}$ & black & B \\
\hline & & M. gariepinus & $\begin{array}{l}\text { South Africa, } \\
\text { Namibia }\end{array}$ & $400-2000$ & shrub & zygomorphic & $15-22 \times 7-10^{12}$ & green $^{13}$ & brown & $\mathrm{B}$ \\
\hline & & M. insignis & South Africa & $900-1800$ & shrub & zygomorphic & $15-40 \times 10^{12}$ & $\operatorname{red}^{13}$ & brown & B \\
\hline & & M. major & South Africa & $300-900$ & shrub & zygomorphic & $15-35 \times 10-12^{12}$ & $\begin{array}{l}\text { dark red - } \\
\quad \text { brown }\end{array}$ & brown & B \\
\hline & & M. pectinatus & South Africa & $0-900$ & shrub & zygomorphic & $10-17 \times 5-10^{12}$ & green $^{13}$ & black & B \\
\hline & & M. villosus & South Africa & $1600-2000$ & shrub & zygomorphic & $15-35 \times 10-12^{12}$ & $\begin{array}{l}\text { purple }- \\
\text { brown }^{13}\end{array}$ & black & $\mathrm{B}, \mathrm{I}$ \\
\hline \multirow[t]{2}{*}{ Lamiales } & \multirow[t]{2}{*}{ Bignoniaceae } & $\begin{array}{l}\text { Deplanchea } \\
\text { tetraphylla }\end{array}$ & $\begin{array}{l}\text { New Guinea, } \\
\text { Australia }\end{array}$ & $0-1000$ & tree & zygomorphic & $25 \times 25 \times 10^{14}$ & yellow & $\begin{array}{l}\text { amber - } \\
\text { dark brown }\end{array}$ & $\mathrm{B}, \mathrm{M}$ \\
\hline & & $\begin{array}{l}\text { Fernandoa } \\
\quad \text { magnifica }\end{array}$ & Eastern Africa ${ }^{15}$ & $0-500$ & tree & $\begin{array}{l}\text { broadly } \\
\text { campanulate }\end{array}$ & $50-110$ & yellow - red & $\begin{array}{l}\text { dark brown - } \\
\text { black }\end{array}$ & B?, M? \\
\hline
\end{tabular}




\begin{tabular}{|c|c|c|c|c|c|c|c|c|c|c|}
\hline Order & Family & Species & Distribution & Altitude (masl) & Growth form & Flower form & $\begin{array}{l}\text { Flower size } \\
(\mathrm{mm})^{1}\end{array}$ & Flower colour ${ }^{2}$ & Nectar colour ${ }^{2}$ & $\begin{array}{l}\text { Flower } \\
\text { visitors }^{3}\end{array}$ \\
\hline \multirow{13}{*}{ Malvales } & Lamiaceae & $\begin{array}{l}\text { Leucosceptrum } \\
\text { canum }\end{array}$ & $\begin{array}{l}\text { Himalaya to } \\
\text { China }^{16}\end{array}$ & $610-2600$ & $\begin{array}{c}\text { shrub - } \\
\text { small } \\
\text { tree }\end{array}$ & campanulate & $8-10 \times 6$ & $\begin{array}{c}\text { white - } \\
\text { cream }\end{array}$ & dark brown & $\mathrm{B}, \mathrm{I}$ \\
\hline & \multirow[t]{12}{*}{ Malvaceae } & $\begin{array}{c}\text { Dombeya } a . \text { ssp. } \\
\text { acutangula }\end{array}$ & La Réunion & $0-1200$ & $\begin{array}{l}\text { tree } \\
\text { shrub - } \\
\text { small } \\
\text { tree }\end{array}$ & $\begin{array}{l}\text { broadly } \\
\text { campanulate }\end{array}$ & 20-30 (diameter) & $\begin{array}{c}\text { white - } \\
\text { cream }\end{array}$ & yellow & $\mathrm{B}, \mathrm{I} \dagger$ \\
\hline & & D. a. ssp. palmata & La Réunion & nd & $\begin{array}{c}\text { shrub - } \\
\text { small } \\
\text { tree }\end{array}$ & $\begin{array}{l}\text { broadly } \\
\text { campanulate }\end{array}$ & 20-25 (diameter) & $\begin{array}{l}\text { white - } \\
\text { cream }\end{array}$ & yellow & $\mathrm{B}, \mathrm{I}, \mathrm{I} \dagger$ \\
\hline & & D. a. ssp. rosea & Mauritius & $200-600$ & $\begin{array}{l}\text { shrub - } \\
\text { small tree }\end{array}$ & $\begin{array}{l}\text { broadly } \\
\text { campanulate }\end{array}$ & 20-25 (diameter) & pink & yellow & $\mathrm{B}, \mathrm{I}, \mathrm{I} \dagger$ \\
\hline & & D. cacuminum & Madagascar & $\begin{array}{l}\text { montane } \\
\text { forests }\end{array}$ & tree & campanulate & 40 & red & yellow & $\mathrm{M}, \mathrm{B}$ ? \\
\hline & & D. elegans & La Réunion & $800-1800$ & $\begin{array}{l}\text { shrub - } \\
\text { small tree }\end{array}$ & campanulate & $10-14$ & pink & yellow & B \\
\hline & & D. kefaensis & Ethiopia & 2200 & shrub & campanulate & $13-17$ & $\begin{array}{l}\text { white - } \\
\text { pale pink }\end{array}$ & red & $\mathrm{u}$ \\
\hline & & $\begin{array}{l}\text { Trochetia } \\
\quad \text { blackburniana }\end{array}$ & Mauritius & $300-700$ & $\begin{array}{l}\text { shrub - } \\
\quad \text { small tree }\end{array}$ & campanulate & $15-25 \times 18-25$ & $\begin{array}{l}\text { pale pink - } \\
\text { red }\end{array}$ & $\begin{array}{l}\text { clear - } \\
\text { amber }\end{array}$ & $\mathrm{B}, \mathrm{L}, \mathrm{I} \dagger$ \\
\hline & & T. boutoniana & Mauritius & $400-600$ & $\begin{array}{l}\text { shrub - } \\
\quad \text { small tree }\end{array}$ & campanulate & $45-50 \times 45-50$ & $\begin{array}{l}\text { pink - } \\
\text { red }\end{array}$ & $\begin{array}{l}\text { orange - } \\
\text { red }\end{array}$ & B, L, I†े \\
\hline & & T. granulata & La Réunion & $1200-1600$ & shrub & campanulate & $36-41 \times 29-32$ & white & yellow & $\mathrm{B}, \mathrm{I} \dagger$ \\
\hline & & T. parviflora & Mauritius & $300-600$ & shrub & crateriform rotate & $8-11 \times 18-21$ & $\begin{array}{l}\text { white - } \\
\text { pale pink }\end{array}$ & $\begin{array}{l}\text { clear- } \\
\text { yellow }\end{array}$ & $\mathrm{u}, \mathrm{I}$ ? \\
\hline & & T. triflora & Mauritius & $500-700$ & $\begin{array}{l}\text { shrub - } \\
\text { tree }\end{array}$ & $\begin{array}{l}\text { broadly } \\
\text { campanulate }\end{array}$ & $25-40 \times 50-70$ & white & yellow & $\mathrm{B}, \mathrm{I} \dagger, \mathrm{M}$ ? \\
\hline & & T. uniflora & Mauritius & $400-700$ & shrub & campanulate & $25-30 \times 19-28$ & pink - red & $\begin{array}{l}\text { orange - } \\
\text { red }\end{array}$ & $\mathrm{B}, \mathrm{I} \dagger$ \\
\hline Myrtales & Combretaceae & Lumnitzera littorea & Guam $^{17}$ & lowland, coastal & $\begin{array}{l}\text { shrub - } \\
\text { tree }\end{array}$ & campanulate & $8-10 \times 8-10^{18}$ & red & orange & $\mathrm{B}, \mathrm{I}$ \\
\hline Poales & Bromeliaceae & Puya alpestris & Chile & $1000^{19}$ & shrub & $\begin{array}{l}\text { tubular- } \\
\text { campanulate }\end{array}$ & 50 & blue & $\begin{array}{l}\text { pale pink - } \\
\text { blue }\end{array}$ & $\mathrm{B}, \mathrm{I}$ \\
\hline \multirow[t]{7}{*}{ Proteales } & \multirow[t]{7}{*}{ Proteaceae } & Banksia grossa & SW Australia & nd & shrub & zygomorphic & $34-45$ & brown & $\begin{array}{l}\text { yellow - } \\
\text { green }\end{array}$ & $\mathrm{I}, \mathrm{M}, \mathrm{B}$ ? \\
\hline & & B. incana & SW Australia & nd & shrub & zygomorphic & $21-23$ & yellow & $\begin{array}{c}\text { yellow - } \\
\text { green }\end{array}$ & $\mathrm{I}, \mathrm{M}, \mathrm{B}$ ? \\
\hline & & B. leptophylla & SW Australia & nd & shrub & zygomorphic & $35-45$ & $\begin{array}{l}\text { yellow - } \\
\text { brown }\end{array}$ & $\begin{array}{c}\text { yellow - } \\
\text { green }\end{array}$ & $\mathrm{I}, \mathrm{M}, \mathrm{B}$ \\
\hline & & B. nutans & SW Australia & nd & shrub & zygomorphic & $22-33$ & $\begin{array}{c}\text { purple }- \\
\text { brown }\end{array}$ & yellow & $\mathrm{I}, \mathrm{M}, \mathrm{B}$ ? \\
\hline & & B. sphaerocarpa & SW Australia & nd & shrub & zygomorphic & $24-39$ & brown & $\begin{array}{c}\text { yellow - } \\
\text { green }\end{array}$ & $\mathrm{I}, \mathrm{M}, \mathrm{B}$ ? \\
\hline & & B. telmatiaea & SW Australia & nd & shrub & zygomorphic & $22-25$ & $\begin{array}{l}\text { orange - } \\
\quad \text { pale brown }\end{array}$ & $\begin{array}{l}\text { yellow - } \\
\text { green }\end{array}$ & $\mathrm{I}, \mathrm{M}, \mathrm{B}$ ? \\
\hline & & Grevillea robusta & E Australia & $0-1120$ & tree & zygomorphic & 23 & yellow - red & $\begin{array}{l}\text { pale yellow - } \\
\text { red }\end{array}$ & B, M?, I† \\
\hline \multirow[t]{2}{*}{ Solanales } & \multirow[t]{2}{*}{ Solanaceae } & Capsicum baccatum & South America ${ }^{20}$ & $500-1500$ & $\begin{array}{l}\text { vine }- \\
\quad \text { shrub }\end{array}$ & rotate & $3.5-7^{21}$ & white - cream & $\begin{array}{l}\text { clear- } \\
\text { yellow }\end{array}$ & $\mathrm{u}$ \\
\hline & & C. pubescens & Bolivia $^{22}$ & $1200-2000$ & $\begin{array}{l}\text { vine - } \\
\quad \text { shrub }\end{array}$ & rotate & nd & purple, white & $\begin{array}{l}\text { clear- } \\
\text { yellow }\end{array}$ & I \\
\hline
\end{tabular}




\begin{tabular}{|c|c|c|c|c|c|c|c|c|}
\hline C. еximium & $\begin{array}{l}\text { Bolivia, } \\
\text { Argentina }\end{array}$ & $1500-3000$ & vine & rotate & 20-25 (diameter) & purple, white & $\begin{array}{l}\text { clear - } \\
\text { yellow }\end{array}$ & $\mathrm{u}$ \\
\hline Faltomata aspera & Peru & $0-500 / 1600-2550^{23}$ & subshrub & crateriform rotate & 49 (diameter) & pale yellow-green & red & $\mathrm{u}, \mathrm{B}$ ? \\
\hline 7. biflora & Peru & $2700-3200$ & shrub & urceolate & $13 \times 14$ & pale green & $\begin{array}{l}\text { clear - } \\
\text { orange }\end{array}$ & u. B? \\
\hline 7. herrerae & Peru, Bolivia & $3000-3800$ & shrub & campanulate & $15-20 \times 35-45$ & pale green & red & $\mathrm{u}, \mathrm{B}$ ? \\
\hline 7. leviae & Peru & $2530-3000$ & vining shrub & urceolate-tubular & $12 \times 18-19$ & $\begin{array}{l}\text { red, blue - } \\
\text { purple }^{24}\end{array}$ & red & $\mathrm{u}, \mathrm{B}$ ? \\
\hline 7. ventricosa & Peru & $2500-3200$ & shrub & urceolate & $8-10 \times 12-14$ & $\begin{array}{l}\text { white - } \\
\text { pale yellow }\end{array}$ & $\begin{array}{l}\text { orange - } \\
\text { red }\end{array}$ & $\mathrm{u}, \mathrm{B}$ ? \\
\hline f. weberbaueri & Peru & $3300-3700$ & subshrub & $\begin{array}{l}\text { broadly } \\
\text { campanulate }\end{array}$ & $40-45 \times 55-60$ & $\begin{array}{l}\text { pale green - } \\
\text { violet }\end{array}$ & red & u, B?, I? \\
\hline f. sp. ' $642^{225}$ & Peru & $2630-2650$ & shrub & urceolate & $7-9 \times 14$ & pale green & red & $\mathrm{u}, \mathrm{B}$ ? \\
\hline 7. sp. ' $647^{925}$ & Peru & $3400-3530$ & shrub & $\begin{array}{l}\text { broadly } \\
\text { campanulate }\end{array}$ & $19-27 \times 32-36$ & $\begin{array}{l}\text { pale green - } \\
\text { purple }\end{array}$ & $\begin{array}{l}\text { clear - } \\
\text { orange }\end{array}$ & $\mathrm{u}, \mathrm{B}$ ? \\
\hline
\end{tabular}

${ }^{1}$ Perianth length, or perianth length $\times$ diameter, or as noted.

${ }^{2}$ A dash between two colours indicates an approximate continuous range.

${ }^{3}$ Hypothesised flower visitors from the literature or from personal communications are indicated with a '?', non-native flower-visitors are indicated with a ' $\dagger$ '. Flower visitor codes: $\mathrm{u}=$ unknown, $\mathrm{B}=$ birds, $\mathrm{I}=$ insects, $\mathrm{L}=$ lizards, $\mathrm{M}=$ mammals.

${ }^{4}$ Sepal length (Wagner et al., 2005).

${ }^{5}$ White is the colour of the petaloid sepals.

${ }^{6}$ Refers to the cup-shaped nectary; the flowers are red-brown, rotate and 6-8 $\mathrm{mm}$ in diameter.

${ }^{7}$ First set of numbers refers to corolla length, second set to length of staminal filaments.

8 The small petals are green, while the numerous long staminal filaments are red.

9 South Africa, Mozambique and Zimbabwe.

${ }^{10}$ Asian distributions: H. kerrii is found in China, Cambodia, Laos, S. Vietnam, S. Thailand and Java; H. obovata in India, Indonesia, Thailand and Fiji; and H. diversifolia in Cambodia, Laos, Myanmar, S. Vietnam, Malaysia, Singapore, Thailand and Indonesia.

${ }^{11}$ Colour refers to corolla; the prominent central corona is pink - purple in all species (see Fig. 2B,C).

${ }^{12}$ Size of outer sepals.

13 Colour refers to the large sepals; the small petals are red or orange, but are mostly hidden inside the sepals (however, see main text on Melianthus).

${ }_{15}^{14}$ Length, height and diameter of corolla, respectively.

15 Malawi, Mozambique, Zimbabwe, Kenya, Tanzania.

16 Bhutan, China, India, Laos, Myanmar, Nepal, Vietnam.

${ }^{17}$ Guam is the only place where coloured nectar has been observed in this species. The total distribution is very wide; ranging from East Africa to Australia and the Western Pacific, but nothing is known about nectar colour in these regions.

${ }^{18}$ Diameter $\times$ depth of flower cup, including the part formed by the calyx.

${ }^{19}$ Average altitude for coastal hill and Andean.

${ }^{20}$ Distribution of the wild progenitor: Bolivia, Argentina, Peru, Paraguay, Brazil.

${ }^{21}$ Length of corolla lobe.

22 Most likely origin of wild progenitor.

${ }^{23}$ Lower range is from the coastal Lomas habitat, higher range from the Andes Mountains.

24 Tube is red, limb is blue - purple.

${ }^{25}$ Numbers refer to accessions by Mione, Leiva and Yacher. 
vryheidensis, one of the species with dark brown nectar, is effectively pollinated by a variety of non-specialised nectarivorous birds, including white-eyes, bulbuls and rock thrushes (Johnson, Hargreaves \& Brown, 2006; Fig. 2R). Earlier anecdotal records indicate that pollination by these occasional nectarivores also occurs in other members of Aloe section Anguialoe (Skead, 1967; Cheke \& Mann, 2001). The experiments conducted by Johnson et al. (2006) showed that artificial
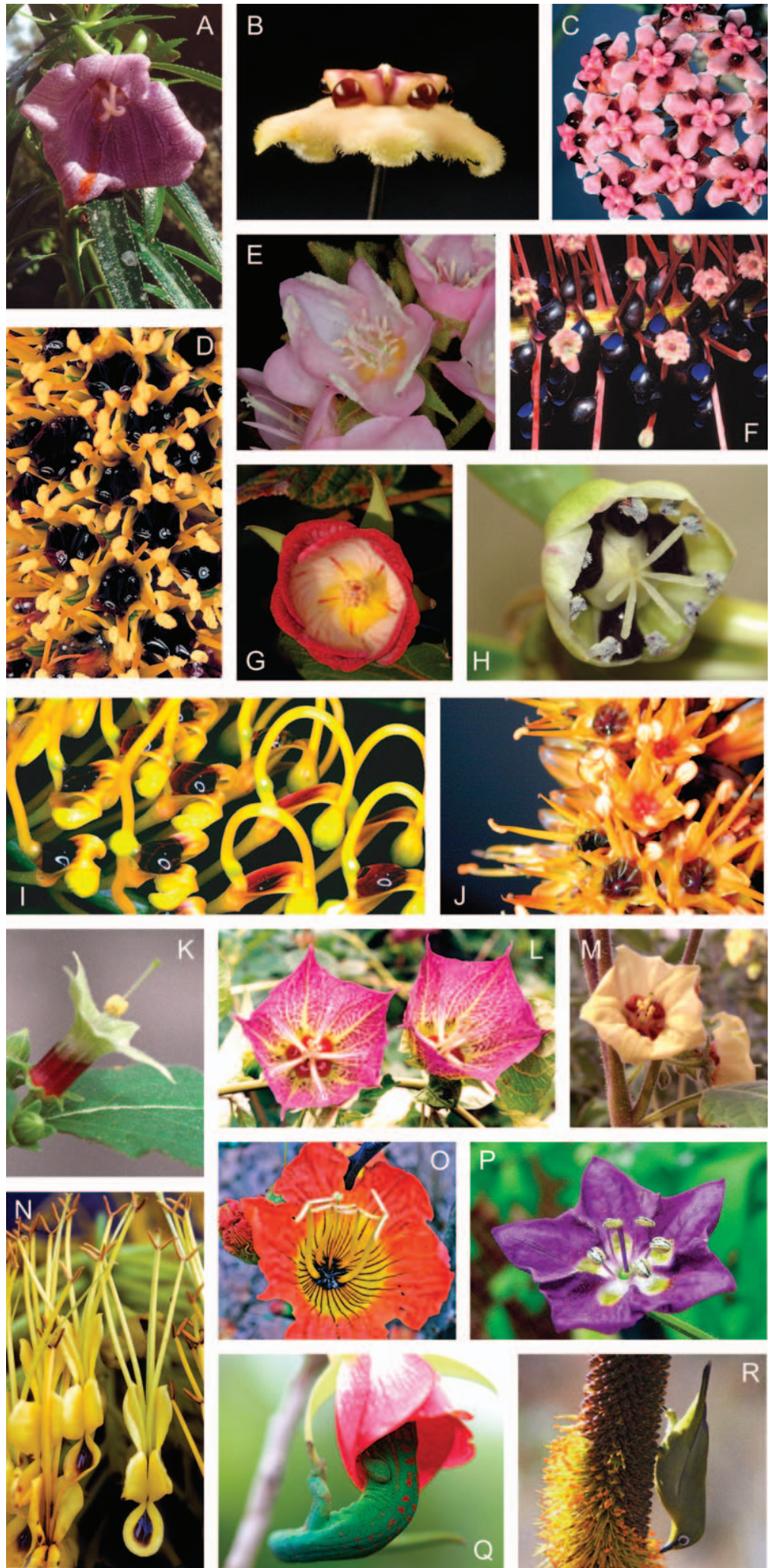

Q

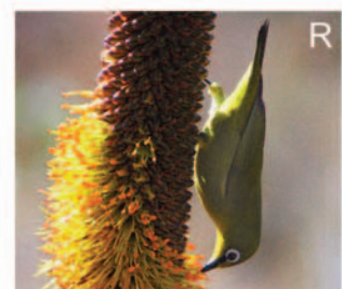




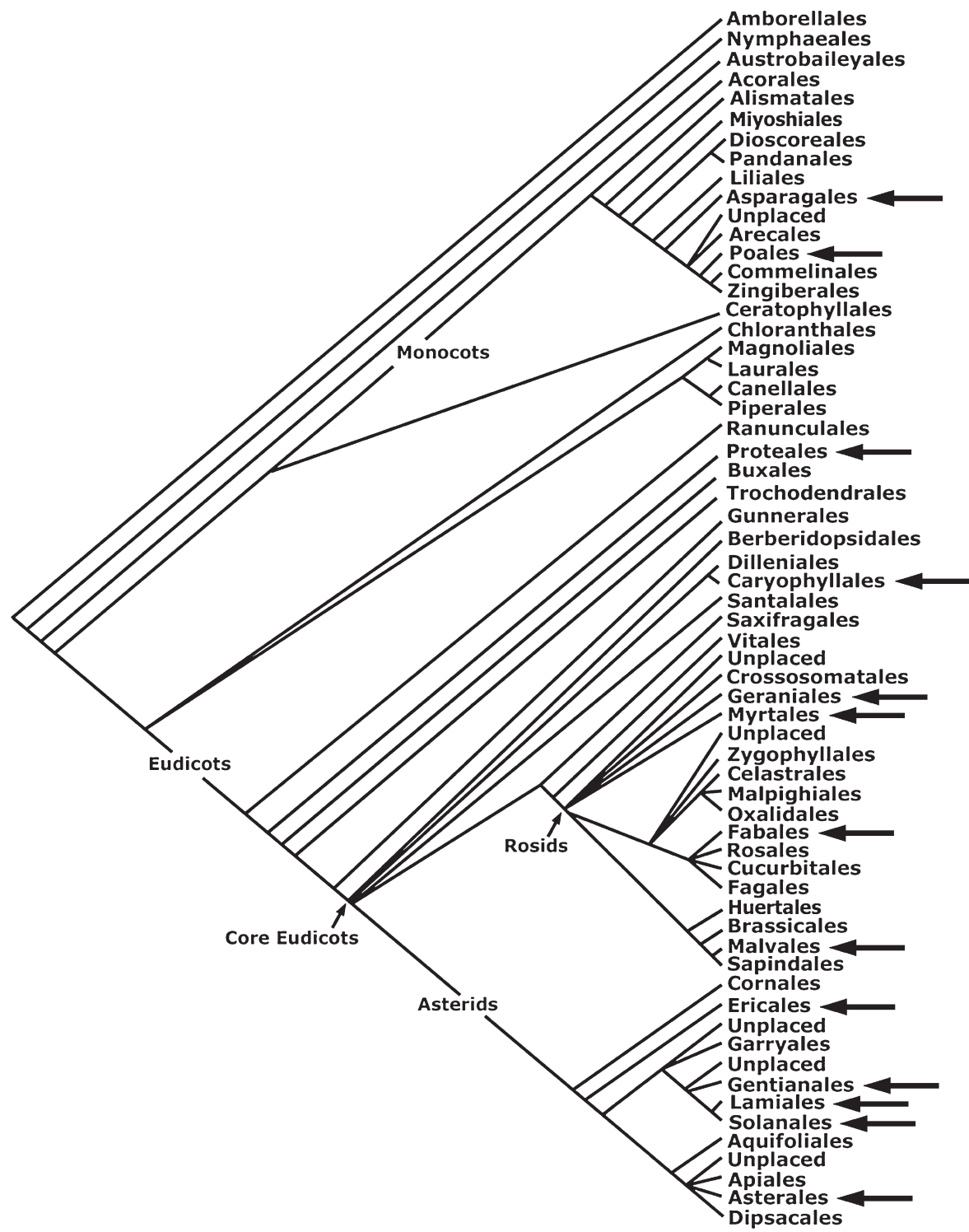

Fig. 3. Taxonomical distribution of coloured nectar in the angiosperms at the level of order. Arrows indicate the presence of one or more taxa with coloured nectar in the respective orders (see Table 1 for details). Figure modified from Stevens (2001 onwards).

flowers with darkened nectar receive more probes by blackcapped bulbuls than do artificial control flowers with clear nectar. However, the main reason why specialised nectarivores such as sunbirds do not visit $A$. vryheidensis is that they find the phenolics in the nectar highly distasteful. Upon probing the flowers and sampling the nectar, these birds would rapidly retract their beaks, shaking their heads vigorously, and not probe such flowers again. Honeybees collect pollen from flowers of $A$. vryheidensis, but find the nectar too unpalatable to consume (Johnson et al., 2006).

Fig. 2. Flowers of plant species with coloured nectar, illustrating the wide variety in flower form, colour and nectar colour. (A) Nesocodon mauritianus (Campanulaceae). (B) Hoya diversifolia (Apocynaceae), single flower, side view. (G) Hoya diversifolia, inflorescence. (D) Aloe vryheidensis (Asphodelaceae). (E) Dombeya angulata ssp. rosea (Malvaceae) - note also the secondary pollen presentation on the tip of the petals. (F) Schwartzia brasiliensis (Marcgraviaceae). (G) Trochetia blackburniana (Malvaceae). (H) Schiedea obovata (Caryophyllaceae). (I) Grevillea robusta (Proteaceae). (J) Aloe castanea. (K) Faltomata umbellata (Solanaceae). (L) Faltomata weberbaueri. (M) Faltomata paneroi. (N) Deplanchea tetraphylla (Bignoniaceae). (O) Fernandoa magnifica (Bignoniaceae). (P) Capsicum pubescens (Solanaceae). (Q) Male Phelsuma cepediana gecko nectar feeding in a Trochetia blackburniana flower. (R) Zosterops pallidus nectar feeding on an Aloe vryheidensis inflorescence. Photographs by J. M. Olesen (A, M), P. Wallin (B), K. F. Yap (C), W. Barthlott (D), D. M. Hansen (E, G, Q), I. \& M. Sazima (F), N. Kawakubo (H), N. Eden (I), M. Nepi (J), T. Mione (K), S. Leiva G. (L), A. Weber (N), C. Puff (O), A. Boatman (P), S. D. Johnson (R). 
Table 2. Nectar properties of plant taxa with coloured nectar ('nd' = no data available)

\begin{tabular}{|c|c|c|c|}
\hline Species & Nectar volume $^{1}(\mu \mathrm{l})$ & Sugar concentration $^{1}(\%)$ & Sugar composition ${ }^{2}$ \\
\hline Aloe castanea & $17-100^{3}$ & $6-18^{3}$ & $0.020-\mathrm{HD}$ \\
\hline A. vryheidensis & $27-70$ & $6-17$ & nd \\
\hline Phormium tenax & $135-166^{3}$ & $15.8-20.3^{3}$ & nd \\
\hline Nesocodon mauritianus & $2.2 \pm 0.86^{4}$ & $11-25$ & $\mathrm{HD}$ \\
\hline Schiedea lychnoides & $18.3^{-}$ & nd & $\mathrm{HR}$ \\
\hline S. obovata & 16.6 & nd & $\mathrm{HR}$ \\
\hline S. trinerve & 30.9 & nd & $\mathrm{HR}$ \\
\hline S. viscosa & 6.3 & nd & $\mathrm{HR}$ \\
\hline Schwartzia brasiliensis & $100-150$ & $12.6(5-20)$ & $0.09-\mathrm{HD}$ \\
\hline Calliandra calothyrsus & $5-55$ & nd & nd \\
\hline Erythrina humeana & nd & 14.2 & $0-0.042-\mathrm{HD}$ \\
\hline E. caffra & 300 & $5.5-10$ & $0-0.042-\mathrm{HD}$ \\
\hline Melianthus comosus & $41.7 \pm 5.1$ & $9.7 \pm 0.2$ & $0.020-\mathrm{HD}$ \\
\hline M. dregeanus & $60.3 \pm 3.7$ & $11.5^{-} \pm 0.4$ & nd \\
\hline M. elongatus & $41.9 \pm 2.9$ & $13.1 \pm 0.4$ & nd \\
\hline M. gariepinus & $14.6 \pm 1.8$ & $12.7 \pm 0.5$ & nd \\
\hline M. major & $81.0 \pm 7.2$ & $15.9 \pm 5.0$ & $\mathrm{HD}$ \\
\hline M. pectinatus & $45.0 \pm 4.1$ & $13.5 \pm 0.2$ & nd \\
\hline M. villosus & $60.0 \pm 4.3$ & $11.6 \pm 0.1$ & nd \\
\hline Deplanchea tetraphylla & $280^{5}$ & nd & $\mathrm{HD}$ \\
\hline Dombeya a. ssp. acutangula & $3.7 \pm 1.5$ & $18->50$ & nd \\
\hline D. angulata ssp. rosea & $8.5(\overline{2}-21)$ & $7-11$ & nd \\
\hline Trochetia blackburniana & $30.9(5-72)$ & $22.6(10-42)$ & $0.030-\mathrm{HD}$ \\
\hline T. boutoniana & $49.3(14-78)$ & $30.2(13-48)$ & $0.036-\mathrm{HD}$ \\
\hline T. granulata & $46.7(17-101)$ & $13.3(8.5-23)$ & HD \\
\hline T. triflora & $35.8(15-63)$ & $15.3(10-19)$ & $0.17-\mathrm{HR}$ \\
\hline T. uniflora & $61.1(9-186)$ & $21.6(15-28)$ & $0.027-\mathrm{HD}$ \\
\hline Lumnitzera littorea & $24-52$ & nd & nd \\
\hline Puya alpestris & 410 & 8.2 & $0.05-0.09-\mathrm{HD}$ \\
\hline Banksia leptophylla & nd & $22.0 \pm 3.4$ & $0.35-\mathrm{HR}$ \\
\hline B. sphaerocarpa & nd & nd & $1.10-\mathrm{SD}$ \\
\hline B. telmatiaea & nd & nd & $1.19-\mathrm{SD}$ \\
\hline Grevillea robusta & $19.1 \pm 1.0(9-37)$ & $23.5 \pm 1.5(7-49)$ & $0.11-\mathrm{HR}$ \\
\hline Faltomata biflora & $0-47^{\frac{1}{6}}$ & $14-58$ & nd \\
\hline 7. paneroi & nd & nd & $\mathrm{HD}$ \\
\hline
\end{tabular}

${ }^{1}$ Measurements given as means \pm S.D./S.E., or means with range in parentheses, or as a range.

${ }^{2}$ Classes of sugar composition as defined by Baker \& Baker (1983): hexose-dominant, HD (S/H ratio < 0.1); hexose-rich, HR $(0.1>\mathrm{S} / \mathrm{H}$ ratio $<0.5)$; sucrose-rich, SR $(0.5<\mathrm{S} / \mathrm{H}$ ratio $<1.0)$; sucrose-dominant, $\mathrm{SD}(\mathrm{S} / \mathrm{H}$ ratio $>1.0)$.

${ }^{3}$ Range of mean values.

${ }^{4}$ Production per hour per flower.

${ }^{5}$ Indirect measure; the volume of water a 'nectar-lobe' will hold.

${ }^{6}$ Depending on sexual phase.

\section{(b) Asparagales - Hemerocallidaceae - Phormium}

Phormium is an endemic New Zealand genus with only two species. Phormium tenax grows widespread throughout New Zealand (P. B. Heenan, personal communication). The flowers are orange to dark red, large and tubular, and are borne in clusters on small sub-inflorescences along a main inflorescence stalk that can reach several meters in height. Nectar is produced in large quantities (Table 2), often forming visible drops at the mouth of the corolla tube (J. L. Craig, personal communication). Nothing has been mentioned about $P$. tenax nectar colour in the literature, but yellow colouration of the nectar has been observed in plants in the native range in New Zealand (J. L. Craig, personal communication), and in plants in a botanical garden in South Africa (J. Henning, pers. comm). However, colour- ation of the nectar in $P$. tenax may be an exception, rather than the rule, as other researchers have only observed clear nectar (P. B. Heenan, personal communication). Nectar standing crop is higher in male-phase than in female-phase flowers (Craig \& Stewart, 1988). Hence, any colouration in the nectar may be related to flower age; i.e. it may be a feature of nectar concentration by evaporation, perhaps combined with oxidative processes. The sister species, P. cookianum, has only been observed to have clear nectar in the field (P. B. Heenan, personal communication). The main pollinators of $P$. tenax are birds; specialised honeyeaters as well as more generalised nectarivorous species (Craig \& Stewart, 1988), but two endemic Hoplodactylus gecko species have also been observed visiting the flowers in large numbers (Whitaker, 1987; Towns, 2002). Phormium tenax is a predominantly outcrossing species (Craig \& Stewart, 
1988), although the realised mating system is strongly influenced by local, inflorescence-level competition between selfed and outcrossed flowers (Becerra \& Lloyd, 1992).

\section{(c) Asterales - Campanulaceae - Nesocodon}

Nesocodon mauritianus is a critically endangered Mauritian plant in a monotypic endemic genus, and is only found on vertical cliffs in five small populations. The four populations in the central and northern mountains are very small, with only a few plants each (J.-C. Sevathian, personal communication; V. Florens, personal communication). The largest known population, with some 110-130 plants, is found around the waterfall Cascade Cinq Cents Pieds in the south. The plants are small shrubs, growing on ledges and in crevices in the cliff. The flowers are large and borne singly (Fig. 2A). They last for as long as 10-11 days, with male phase lasting 6-7 days and female phase 3-5 days (J. M. Olesen, unpublished data from greenhouse plants). The red nectar has a $\mathrm{pH}$ as high as 9.2, and the red colour turns yellow at $\mathrm{pH}<7$. The red pigment is an aurone and the yellow pigment is a flavone or a 3-glucolysed flavonol, all of which are products of flavonoid biosynthesis. The only frequent flower visitor is an introduced bird, the redwhiskered bulbul, Pycnonotus jocosus (Olesen et al., 1998). However, the area around Cascade Cinq Cents Pieds and the nearby Alexandra Falls was until the 1980s a stronghold of a critically endangered endemic bird, the Mauritius olive white-eye, Zosterops chloronothos (Cheke, 1987b). This bird would be a likely pollinator, as it is the most specialised nectarivore in the genus and it visits many other Mauritian plants for nectar (Gill, 1971; Safford, 1991; Hansen, Olesen \& Jones, 2002). Furthermore, the endemic diurnal gecko, Phelsuma ornata, is common on the mountain slopes of the central and northern $\mathcal{N}$. mauritianus populations. Mauritian Phelsuma geckos are known to be regular flower visitors and pollen vectors of many plant species (Nyhagen et al., 2001; Olesen, Eskildsen \& Venkatasamy, 2002; Hansen et al., in press; C. N. Kaiser, personal communication); P. ornata is likely to play a role in the pollination of the northern $\mathcal{N}$. mauritianus populations, but no studies have been made in these populations yet. Interestingly, recent studies have found that $P$. ornata geckos show a strong preference for coloured over clear nectar in artificial flowers (Hansen, Beer \& Müller, 2006), and that $P$. cepediana geckos are efficient pollinators of another, unrelated Mauritian endemic plant with coloured nectar, Trochetia blackburniana (Malvaceae) (Hansen et al., in press).

\section{(d) Caryophyllales - Caryophyllaceae - Schiedea}

Schiedea is a genus in the endemic Hawaiian subfamily Alsinoideae, comprising 34 species, four of which have black nectar (Table 1). These four species are divided into sections Alsinidendron and Nothoschiedea, which together are nested monophyletically within Schiedea (Wagner, Weller \& Sakai, 2005). Schiedea is one of the most remarkable examples of adaptive radiation among Hawaiian angiosperms, with a large number of evolutionary shifts in morphology, breeding systems, ecological adaptations and pollination biology (Weller \& Sakai, 1990; Weller et al., 1990; 1998). The four species with black nectar are found on two different islands in the Hawaiian archipelago (Table 1). The Kaua'i species are herbaceous vines, while the O'ahu species are woody shrubs and thus probably longer lived. In the greenhouse, the Kaua'i species live longer than one year, so they are not strict annuals (S. G. Weller, personal communication). The flowers are apetalous but have white or pale green petaloid sepals (Fig. 2H). Older taxonomical treatments of these species do not mention the black nectar (e.g. Mann, 1866; Sherff, 1944). The first published evidence of the coloured nectar is found in Weller \& Sakai (1990), in which a colour photograph of $S$. lychnoides shows a large drop of black nectar on the tip of a petaloid sepal. Later, Weller, Sakai \& Wagner (1995) reported that "nectar appears black when large amounts accumulate". In a new taxonomical revision of the genus the black nectar is finally mentioned in the description of the four species (Wagner et al., 2005). The black nectar in Schiedea may be related to ornithophily (Weller et al., 1998; Wagner et al., 2005), but there are no observations of birds visiting the flowers. This is most likely due to the rarity of the plants in the wild, and the fact that much of the Hawaiian nectarivorous avifauna has gone extinct (Wagner et al., 2005; S. G. Weller, personal communication).

\section{(e) Ericales - Marcgraviaceae - Schwartzia}

Schwartzia is a neotropical genus of shrubs with 14 species in the monophyletic subfamily Noranteoideae, which comprises four small genera. While morphologically well supported, recent molecular work suggests that the four genera may not be well delimited within Noranteoideae (de Roon \& Dressler, 1997; Ward \& Price, 2002; Dressler, 2004). Schwartzia brasiliensis is a scrambling, partly epiphytic shrub from Brazil. The branches of $S$. brasiliensis carry long, terminal, brush-like racemes of up to $40 \mathrm{~cm}$ in length, with 60-300 flowers, each of which has the cup-like nectary connected to the base of the peduncle (Fig. 2F) (Sazima, Buzato \& Sazima, 1993; Dressler, 2004). The strikingly blue-coloured nectar in $S$. brasiliensis was reported by Sazima et al. (1993) and Pinheiro et al. (1995), and is produced in vast quantities in each nectary (Table 2). A nectary can hold $100-150 \mu \mathrm{L}$ and produce $50 \mu \mathrm{L}$ of nectar within a 3-hour period, and drops of overflowing nectar can often be observed on the nectaries (Fig. 2F) (Sazima et al., 1993; Pinheiro et al., 1995). The pigment causing the blue colouration of the nectar is an anthocyanin (Sazima et al., 1993). The ruby-red long stalks and flowers, and the dark purple-brown nectaries, contrast well against green foliage (Sazima et al., 1993), and, in turn, the blue nectar is easily visible against the dark nectaries (Fig. 2F). Schwartzia brasiliensis is visited and pollinated by a wide range of birds, including both hummingbirds and perching passerines (Sazima et al., 1993; Pinheiro et al., 1995), and even woodpeckers (Rocca et al., in press). Based on foraging behaviour, Sazima et al. (1993) suggested that perching passerine birds were more likely to be efficient pollinators, than hovering hummingbirds. During night, when the flowers have already wilted, nocturnal insects and perhaps 
bats forage on the remaining nectar, which in old nectaries can smell of cabbage (Sazima et al., 1993).

\section{(f) Fabales - Fabaceae}

(i) Calliandra. This is a large, widespread tropical genus with about 200 species (Mabberley, 1997). Yellow nectar has been observed in $C$. calothyrsus over much of the species' native range (J. R. Chamberlain, personal communication), and also in naturalised and plantation trees in Western Kenya (Jensen, 2005) and the Philippines, where honey bees produce a green honey based on the yellow nectar (Estolas, 2004). The native range of $C$. calothyrsus stretches from southern Mexico to central Panama (Chamberlain, 1998), but the species is also widely used in many tropical countries for agroforestry, fodder and honey production (Palmer, Macqueen \& Gutteridge, 1994; Chamberlain, 2000). The mimosoid flowers are small and green and are borne in large umbelliform clusters, but each flower has numerous red staminal filaments of 4-6 cm in length. Many different flower visitors have been observed in the native range of $C$. calothyrsus: bats, birds, large hawkmoths, honey bees and other insects. However, the nocturnal short anthesis of individual flowers means that the only efficient pollinators are bats and large hawkmoths (Palmer et al., 1994; Chamberlain, 2000). If the plentiful nectar is left unharvested overnight, birds will feed on it in the morning until the flowers wilt and drop off, but by then the stigma is no longer receptive. Non-native honey bees and other insects also visit the flowers in the morning, but they all approach the nectar at the bottom of the flowers and never touch the fertile parts, and are thus unlikely pollinators (Chamberlain, 2000; Jensen, 2005).

(ii) Erythrina. A genus with 112 species, found both in paleotropical and neotropical regions (Bruneau, 1996; Mabberley, 1997). Coloured nectar was reported by Guillarmod, Jubb \& Skead (1979) in three species of the two closely related small sections Humeanae and Caffrae (Krukoff \& Barneby, 1974; Bruneau, 1996; 1997), but nothing more is known about coloured nectar in Erythrina. The flowers are usually grouped in large inflorescences, and are strongly zygomorphic, with most of the inner petals usually being enclosed by the large outer standard. Thus, the nectar is rarely visible from outside, and the relatively weak colours of the nectar are probably not visible against the bright red corollas (Table 1). The nectar colours reported by Guillarmod et al. (1979) may be due to local edaphic (e.g. pH or nutrient levels) or climatic factors in the areas where they investigated the plants, as other researchers have failed to notice any significant colouration of the nectar in these species (S. W. Nicolson, personal communication; F. Forest, personal communication). The genus is believed to be entirely ornithophilous, and flowers of most species produce large quantities of nectar. However, insects, lizards and mammals have also been observed visiting flowers, but mostly in very low numbers (Scott-Elliot, 1890; Raven, 1974; Toledo, 1974; Bruneau, 1997; Sazima, Sazima \& Sazima, 2005). Guillarmod et al. (1979) report that the three species with col- oured nectar are visited by a wide range of nectar-feeding bird species.

(g) Gentianales - Apocynaceae - Hoya

Hoya is a large, tropical genus with 200-300 currently recognised species. It is found throughout most of the IndoAustralian region. The centres of diversity are found in the Indonesian archipelago, with approximately 25 species in Malaysia, 74 in New Guinea and $>30$ species in the Philippines (Forster, Liddle \& Liddle, 1998; Kleijn \& van Donkelaar, 2001; Wanntorp, Kocyan \& Renner, 2006; Wanntorp et al., in press). Hoya belongs to the subfamily Asclepiadoideae, which has the most elaborate and complex floral structure of all eudicots (Endress, 1994). Most Hoya species grow as vines or arboreal shrubs, with flowers arranged in umbels. Apart from information on their habitat, almost nothing is known about their ecology. However, many species are popular as ornamental plants (waxflowers, porcelain flowers), and it is from dedicated hobby plant growers that we received much of the information on coloured nectar in this genus. Many Hoya species produce large amounts of nectar, which forms visible drops on the flat corollas of the flowers, including the ones with coloured nectar (Fig. 2B,C). Coloured nectar is only found in the five species of section Amblyostemma (Table 1), and Kloppenburg (1994) included "exuding a coloured honeydew" in his list of diagnostic characters (synapomorphies; specialised characters shared by two or more species, originating in their last common ancestor) for the section. Nothing is known about the nectar properties or pollination biology of any of the species in this section. The only study of pollination biology in Hoya is from Australia, in which Forster (1992) found $H$. australis to be pollinated by Lepidoptera. In fact, the asclepiads were thought to be strictly entomophilous (Ollerton \& Liede, 1997), until Pauw (1998) elegantly demonstrated tonguepollination by sunbirds in one species.

\section{(h) Geraniales - Melianthaceae - Melianthus}

Melianthus is a small South African genus with eight species in what has been called an enigmatic Southern African family, whose taxonomy and floral morphology have long puzzled botanists (Ronse Decraene et al., 2001). The petals are small, fused and red or pinkish, and are mostly hidden in a cup formed by the large sepals. However, in some of the species, namely $M$. elongatus, $M$. pectinatus and $M$. gariepinus, the petals are large and showy enough to be considered as the main visual attractant of the flowers (J. Henning, personal communication). In some of the species, the large drop of dark nectar can be seen not only from the front of the flowers, but also from the sides because the sepals are pale, thin and translucent (Fig. 1). The dark nectar in Melianthus has been known at least since 1795 (see Section I), and has received anecdotal references in publications since then (e.g. Scott-Elliot, 1890; Dyer, 1952; Archer \& Condy, 1997). It is unclear to what extent Melianthus species vary in nectar colour within and between species; whereas $M$. comosus, $M$. elongatus and $M$. villosus have all been 
observed to have black nectar, most of the remaining species have brown nectar ( J. Henning, personal communication). No thorough pollination study has been carried out, but both insects and birds have been observed visiting Melianthus species for nectar. Scott-Elliot (1890) reported that the "abundance of rich black honey which sometimes almost fills the cup" was eagerly sought by sunbirds, and Marloth (1925) remarked that "the nectar of $M$. comosus is so dark that the honey taken from the hives of bees which feed on it is quite black". Mabberley (1997) also includes, in his characteristic shorthand, the intriguing comment "fls rich in nectar (black, taken by sunbirds)".

\section{(i) Lamiales - Bignoniaceae}

(i) Deplanchea. A genus with five species, ranging from Sumatra to New Caledonia. Deplanchea tetraphylla is a large tree, found in New Guinea, the Aru Islands, and North East Queensland, Australia (Avé, 1984). It is apparently the only species in the genus with coloured nectar, which it presents in a most spectacular and specialised manner. Its large yellow flowers are clustered in large, circular and flat inflorescences at the end of upper branches. Each flower is strongly zygomorphic with a lower central corolla lobe forming a spoon-like hollow where the dark-brown nectar accumulates (Fig. 2N; Weber \& Vogel, 1986). Known flower visitors include birds (Brown \& Hopkins, 1995) and mammals (Jackson, 2001). Weber \& Vogel (1986) concluded that birds were most likely to be the main pollinators throughout most of the range of $D$. tetraphylla. Furthermore, they stated that the easy, open access to the nectar is suggestive of pollination by relatively short-beaked, generalised nectar-feeding birds, such as lorikeets. In Australia, birds and large butterflies visit the flowers in great numbers $(\mathrm{G}$. Sankowsky, personal communication). Weber \& Vogel (1986) suggested that the brown pigment in the nectar was a melanin. Furthermore, they remarked that in New Guinea, younger flowers were seen with honey-coloured nectar, while older flowers had darker brown nectar.

(ii) Fernandoa. A genus with 14 species with a paleotropical distribution stretching from Africa and Madagascar to China, South-east Asia and Sumatra (Mabberley, 1997). Fernandoa magnifica is a large central-eastern African tree. It often flowers while leafless; inflorescences consist of cymes of 4-10 upwards-turned, large campanulate flowers (Dale \& Greenway, 1961). The flowers are red at the top, grading through orange to yellow at the base, where copious amounts of dark brown, almost black nectar forms a small pool (Fig. 2O). Pollinators are unknown, but the flowers have an unpleasant, cabbage-like smell (C. Puff, personal communication, M. Hyde; personal communication), which may be indicative of bat-pollination (Knudsen \& Tollsten, 1995). However, the large, colourful flowers also suggest that birds may be attracted to the flowers and act as pollinators, and there are plant species that are pollinated by both bats and birds (Sazima, Sazima \& Buzato, 1994; Muchhala, 2003). Almost nothing is known about nectar colour in the rest of the genus, but the Malagasy F. madagascariensis has 6$7 \mathrm{~cm}$ large ornithophilous flowers with small amounts of clear nectar (J. M. Olesen, personal observations).

\section{(j) Lamiales - Lamiaceae - Leucosceptrum}

Leucosceptrum is a very small genus with three species, found from the Himalayas to China (Mabberley, 1997). Leucosceptrum canum is a common species, with small, cream-white flowers arranged in dense, terminal spikes. Nothing is noted about its dark brown nectar in the literature, the only information is from an observation in a commercial nursery in the Indian Himalayas (G. M. Pradhan, personal communication). The species is known as a honey plant ( $\mathrm{Li} \&$ Hedge, 1994), and Cowan \& Cowan (1929) remarked that, "a quantity of sweet juice exudes from the flowers, and this is sucked by Paharia herdsmen, and by many birds". The former are probably less efficient than the latter as pollinators, though, and it can therefore be assumed that the plant is ornithophilous. A study on the species in China (Caihuan et al., 2004) identified a yellow pigment from the flowers as an amine, but it is not clear whether the pigment analysed was from the floral parts or the nectar.

\section{(k) Malvales - Malvaceae}

(i) Dombeya. A large, widespread genus with about 225 recognised species in Africa, Madagascar and some of the Indian Ocean islands (Mabberley, 1997). The evolutionary hotspot and likely origin of Dombeya is in Madagascar (including the Comoros Islands) with approximately 190 species. The Ethiopian D. kefaensis, the Malagasy D. cacuminum and the Mascarene D. elegans, D. acutangula ssp. acutangula, D. acutangula ssp. palmata and D. acutangula ssp. rosea are the only known Dombeya with coloured nectar. In the taxonomical description of $D$. kefaensis, Friis \& Bidgood (1998) mention a dark orange nectar stain at the base of each petal, and in their Fig. 2 the dark red nectar is clearly seen, contrasting with the pale cream petals. Malagasy $D$. cacuminum plants in cultivation elsewhere have been reported to produce abundant musky-scented yellow nectar (Llamas, 2003). Another rare floral trait, secondary pollen presentation on the tip of the petals, has been reported for this species (Prenner, 2002). Together, these two floral traits could suggest a combination of bird- and bat pollination for D. cacuminum (Llamas, 2003). In a revision of continental African Dombeya species, Seyani (1991) lamented the fact that virtually nothing is known about their pollination biology. However, there have been some studies of the reproductive biology of Dombeya spp. on the island of La Réunion (Gigord, Lavigne \& Shykoff, 1998; Gigord, Picot \& Shykoff, 1999; Humeau \& Thompson, 2001 and references therein), with a few of those studies providing anecdotal observations on flower visitors. In two studies of D. acutangula ssp. acutangula, Gigord et al. (1998, 1999) mention insects and birds visiting the flowers that produce large quantities of nectar. There is no reference to the yellow colour of the nectar in any of the studies mentioned above, but it is always strikingly yellow when present (L. Gigord, personal communication). The majority of Dombeya species have flowers with either white or pinkish corollas, and many have large, showy inflorescences with rather small flowers. The small, white-flowered species are probably pollinated mainly by insects, whereas 
larger, pinkish and red ones such as $D$. lastii may be bird pollinated (Seyani, 1991). Indeed, D. goetzenii with pale pink flowers that are deep red at the base of the staminal tube (Dale \& Greenway, 1961) is visited by several sunbird species (Cheke \& Mann, 2001).

(ii) Trochetia. An endemic Mascarene genus encompassing six species of shrubs and small trees; five species in Mauritius and one in La Réunion. All six species have coloured nectar, and show a remarkable variation in flower morphology and colour among species (Fig. 2G; Table 1; Friedmann, 1987). Their proposed closest relatives include several Malagasy Dombeyoid genera (Friedmann, 1987). The most commonly reported pollinators of the Mauritian Trochetia species are two nectarivorous endemic bird species: the Mauritius grey white-eye, Zosterops mauritianus, has been observed visiting T. blackburniana, and the Mauritius olive white-eye, Z. chloronothos, has been observed on T. uniflora and has repeatedly been suggested as the main pollinator of T. blackburniana (Gill, 1971; Staub, 1988; Safford, 1991; Hansen et al., 2002). Furthermore, Z. chloronothos has been suggested as a pollinator of the endangered T. boutoniana (Staub, 1988). In La Réunion, both endemic species of Zosterops have been observed visiting T. granulata (Gill, 1971; D. M. Hansen, personal observations). An anecdotal observation of an endemic diurnal gecko visiting a flower of T. blackburniana (Staub, 1988) has recently been confirmed by a study which shows that Mauritian Phelsuma geckos are important pollinators of T. blackburniana (Fig. 2Q; Hansen et al., in press). Phelsuma geckos have been confirmed to visit a wide range of other Mauritian endemic plant species (Nyhagen et al., 2001; Olesen et al., 2002; D. M. Hansen, personal observations; C. N. Kaiser, personal communication), and in a recent study $P$. ornata geckos strongly preferred coloured over clear nectar in experimental artificial flowers (Hansen et al., 2006). More studies on how Phelsuma geckos interact with Mauritian plants with coloured nectar in the wild are needed to assess the effect of coloured nectar on reproductive success. Trochetia blackburniana may be well suited for such studies, as its nectar naturally varies from clear to deep yellow or orange, even within small populations, while variation in nectar colour of flowers on the same plant seems to be smaller (D. M. Hansen, personal observations).

Dombeya and Trochetia both belong to the subfamily Dombeyoideae. It seems curious that the occurrence of coloured nectar within Dombeyoideae in Madagascar, the evolutionary hotspot of the subfamily, should be restricted to $D$. cacuminum. It is very likely that further field studies will reveal coloured nectar in more of the Malagasy Dombeyoid genera or species. Given the wide distribution of many Dombeya species in Africa (Seyani, 1991), it is also likely that coloured nectar will be found in additional African species.

\section{(l) Myrtales - Combretaceae - Lumnitzera}

Lumnitzera is a genus with only two species, both of which are widespread in mangrove forests from East Africa to the Western Pacific and tropical Australia (Tomlinson, 1986).
Lumnitzera littorea has terminal inflorescences with small, red flowers, exerted stamens and a cup formed by the calyx, allowing for abundant nectar to accumulate (Table 2). The flowers thus fit well into the general ornithophilous syndrome, and are predominantly visited by sunbirds and honeyeaters, but also by bees and wasps (Tomlinson, 1986). Yellow nectar in $L$. littorea has only been reported from Guam (H. Skovsgaard, personal communication), but nothing is known about nectar colour anywhere else in this species' wide range. However, the nectar of plants of the sister species, L. racemosa, growing in the Fairchild Botanical Garden, Florida, USA, was observed to be clear (P. B. Tomlinson, personal communication).

\section{(m) Poales - Bromeliaceae - Puya}

Puya is a terrestrial bromelioid genus with almost 200 species that are mainly found on the slopes of the Andes Mountains from Chile to Columbia (Smith \& Downs, 1974). Recent molecular taxonomical work assigned Puya as a monophyletic sister genus to the subfamily Bromelioideae (Terry, Brown \& Olmstead, 1997; Givnish et al., 2004). The subgenus Puya comprises eight species with large, terminal, columnar, and multibranched inflorescences (HornungLeoni \& Sosa, 2004); the most well known being the Peruvian P. raimondii - the 'Queen of the Andes' - which grows to 10-12 m in total height (Sgorbati et al., 2004). Puya alpestris is confined to Chile, and is smaller, with an inflorescence of 1-1.5 $\mathrm{m}$ and up to $2 \mathrm{~m}$ total height (Hornung-Leoni \& Sosa, 2006). Each branch on the inflorescence carries several large flowers of a striking blue colour with bright orange pollen. Nectar is produced in vast quantities, and sometimes it drips out of the flowers. In the wild, the nectar has been observed to be varying in colour from pale pink to a red-wine like colouration (C. HornungLeoni, personal communication). In plants grown in gardens in California and in the UK it has been reported to be of a blue colour (Dortort, 2003; D. Poole, personal communication). In all species of subgenus Puya, the terminal half of each branch is sterile, with only bracts and no flowers. This was proposed by Johow (1898) to be an adaptation to pollination by perching nectar-feeding birds, which are the main pollinators of the subgenus - as opposed to the subgenus Puyopsis, which is mainly hummingbirdpollinated and lacks such perches. This dichotomy is reflected in the nectar composition as well: nectars from subgenus Puyopsis are sucrose-rich and of relatively high concentration, while nectars from subgenus Puya are relatively dilute and hexose-rich (Table 2; Scogin \& Freeman, 1984; Baker \& Baker, 1990). Observed pollinators of $P$. alpestris include the Austral blackbird, Curaeus curaeus, and Castnia eudesmia, a large diurnal moth that also passes its larval and pupal stages on Puya alpestris, and which is known occasionally to drive off other moths and birds (!) from the flowers (Gourlay, 1950; Ortiz-Crespo, 1973). Nothing is known about what causes the blue colouration of the nectar, but an unusual floral anthocyanin, delphinidin 3,7,3'triglucoside, has been identified as the main petal colour pigment (Scogin \& Freeman, 1984; Scogin, 1985), and it could be related to the nectar colouration as well. Coloured 
nectar is not known from any other Bromeliaceae, and a recent study of nectar from 110 bromeliad species from 16 genera, including five Puya species, found all of these to be clear (T. Krömer, unpublished data).

\section{(n) Proteales - Proteaceae}

(i) Banksia. An Australian genus with 73 species (Mabberley, 1997). Five Banksia species from the Sphaerocarpa group (series Abietinae) were reported to have an initially yellow nectar, which turns olive to dark green, almost black, and gelatinous during anthesis (Lamont, 1980; Markey \& Lamont, 1995). The dark nectar is easily seen deep in the inflorescence, between the long filaments (Fig. 1 in Lamont, 1980). The nectar of another species, $B$. nutans, remains a translucent yellow throughout anthesis. At first this was assumed to be a secondary effect of a presence of cyanobacteria, but a subsequent analysis rejected this hypothesis (Markey \& Lamont, 1995). What causes the colouration of the nectar is still unknown (B. B. Lamont, personal communication). However, it is likely to be a chemical process in the nectar itself, as a colour change also occurs in freshly secreted yellow nectar after storage in sterile tubes (Markey \& Lamont, 1995). The inflorescences of all Banksia species in series Abietinae are spherical, relatively close to the ground, and produce large volumes of nectar. Observed pollinators and flower visitors include honeyeaters, ants, flies and beetles. The strong, musky smell of the flowers of these species also suggests nocturnal mammals, and scats have often been found on inflorescences, lending further credibility to this hypothesis (Markey \& Lamont, 1995; B. B. Lamont, personal communication). Indeed, several nonflying mammals, e.g. the honey possum, are efficient pollinators of Australian plants, including several Banksia species (Carthew \& Goldingay, 1997; Wooller \& Wooller, 2003).

(ii) Grevillea. A large Australasian genus with 261 species, many of which are ornithophilous (Mabberley, 1997). Ornamental Grevillea robusta plants in South Africa and Kenya have been reported to have yellow nectar, and red nectar has been observed in a greenhouse plant in Germany (Kalinganire et al., 2001; Nicolson, 1993; 1995; J. Henning, personal communication), but curiously nobody has reported coloured nectar from its native range in Australia (R. O. Makinson, personal communication). The red colouration at the base of the petals makes the yellow nectar seem almost orange (Fig. 2I). There are many observations of nectar-feeding birds on the flowers of $G$. robusta in its native range (Makinson, 2000), and native flying foxes (Pteropus, Macrochiroptera) have also been observed visiting the flowers (R. O. Makinson, personal communication).

\section{(o) Solanales - Solanaceae}

(i) Capsicum. Also known as chilli-peppers, Capsicum is a neotropical genus with 20-27 recognised species. Chilli peppers have been cultivated in many parts of South America for 7000-8500 years, and are now grown in many parts of the world (Walsh \& Hoot, 2001). The genus is closely related to Faltomata (Vogel, 1998). Yellow nectar is found in species from the earliest diverging branches of the phylogeny of the genus, in the two closely related groups Eximium and Baccatum, and in the unassigned species C. pubescens (Walsh \& Hoot, 2001). The yellow nectar is visible as well-defined drops on the cream-white corolla of $C$. baccatum. In the purple-flowered species $C$. pubescens and $C$. eximium the yellow nectar contrasts against white spots near the centre of the corolla, and is also clearly visible (Fig. 2P). Despite the current widespread cultivation of at least one of the Capsicum species with coloured nectar (C. baccatum varieties), nothing has previously been published about the yellow nectar it very often produces. The only flower visitors that have been observed on plants with coloured nectar in the field are ants (W. H. Eshbaugh, personal communication). Based on the current understanding of the phylogenetic relationships within the genus (Walsh \& Hoot, 2001) it is likely that more Capsicum species might produce yellow nectar, namely $C$. cardenasii and C. tovarii (W. H. Eshbaugh, personal communication). Self-incompatibility in the genus seems to be facultative; plants typically exhibit self-incompatibility for a period, but if outcrossing does not occur, plants will 'allow' selfpollination and produce a small amount of fruit toward the end of the fruiting season (W. H. Eshbaugh, personal communication).

(ii) Jaltomata. Faltomata is a diverse neotropical genus of 46 species of perennial herbs and shrubs, and is distributed from Arizona, USA, to Bolivia, the Galápagos Islands and the Greater Antilles. A subset of the species that grow in Peru and Bolivia produce orange to red nectar; all other species produce clear nectar. These species represent some of the most striking examples of coloured nectar; for example, Bitter (1924) quoted Weberbauer's vivid description of how 7 . umbellata secretes "blood red juice ... which often fills the whole tube" that can be seen through the pale green corolla - similar to red wine in a glass (Fig. 2K). Faltomata umbellata and 7 . aspera grow in the Lomas formation, a fog-fed desert habitat of the west coast of South America with a high level of endemism (Dillon, 1997). The remaining Faltomata species with coloured nectar grow in higher and moister habitats, at altitudes up to $3800 \mathrm{~m}$ (Table 1). The species with coloured nectar show marked variation in flower shape (Table 1), and have corollas that remain open at night. Among the faltomata species with clear nectar, some species have corollas that remain open at night, and others have corollas that close in the late afternoon and open again the next day. Coloured nectar tends to be produced in greater volumes than clear nectar, but this trend is not absolute. Faltomata paneroi, $\mathcal{7}$. umbellata, $\mathcal{F}$. ventricosa and $\mathcal{F}$. weberbaueri all produce copious red or orange nectar, whereas $\mathcal{f}$. antillana, 7. confinis, 7. grandiflora, 7. procumbens, 7. repandidentata and 7. sinuosa produce clear nectar in minute amounts. Quantitative nectar data are only known for one species with coloured nectar, 7. biflora (Table 2). The nectar in 7. biflora is usually clear but can turn amber or orange in colour as the flower ages (Mione, Mugaburu \& Connolly, 2001). Nothing is known about the pollination biology of 
Faltomata, including the species with coloured nectar. Bitter (1921) quoted a correspondence with Weberbauer, in which he suggested that the red nectar of $\mathcal{f}$. aspera attracts small flies for pollination. Bitter (1921) did not state whether Weberbauer had seen the flies or was speculating, but the size of flowers and the large distance from the nectar to the reproductive surfaces (Fig. 2L) make it unlikely that small flies could act as pollinators. Later, Mione \& Anderson (1996) speculated that the red nectar in Faltomata was related to hummingbird pollination, based on floral morphology and the red colouration common among hummingbird flowers (e.g. Proctor, Yeo \& Lack, 1996).

\section{DISGUSSION}

Our review demonstrates that coloured nectar is geographically and taxonomically widespread, but also relatively rare and poorly documented. However, it is very likely that many more plant species have coloured nectar, and that it has so far been under-reported in the scientific literature. Nevertheless, the information we have presented allows us to discuss environmental and ecological patterns, in addition to the evolution of coloured nectar.

\section{(1) Environmental and ecological correlates of coloured nectar}

The occurrence of coloured nectar seems to be correlated with three factors. Firstly, vertebrate pollination: many plants with coloured nectar are known to or have been hypothesised to be vertebrate-pollinated, mainly by birds (Table 1). Secondly, insularity: Nesocodon mauritianus, Trochetia spp., Dombeya acutangula ssp. acutangula and ssp. rosea, D. cacuminum, as well as the Schiedea spp. are all island endemics, while the majority of the other species are found in insular mainland areas, isolated either by altitude (e.g. most Faltomata spp. and Puya alpestris in the Andes Mountains, Leucosceptrum canum in the Himalayas, and Dombeya kefaensis in Ethiopia), habitat (Jaltomata umbellata and $\mathcal{7}$. aspera grow in the Peruvian Lomas formations vegetation islands surrounded by hyperarid desert) or by biogeographical history (i.e. Aloe spp. and Melianthus spp. in Southern Africa, Hoya spp. in insular Asia, and Banksia spp. and Grevillea robusta in Australia). Thirdly, most plants with coloured nectar occur at high or relatively high altitudes (Table 1) - e.g. for a plant in Mauritius, 600-800 $\mathrm{m}$ is a high altitude, as the maximum height of the island is $828 \mathrm{~m}$.

There are some notable exceptions to the second and third factors listed above, including Hoya, where some species with coloured nectar occur in mainland Asia, and all Hoya species with coloured nectar are lowland plants. Also, Grevillea robusta is found from sea level to higher altitudes, as is Calliandra calothyrsus, Fernandoa magnifica, Deplanchea tetraphylla, Phormium tenax and some of the Melianthus species (Table 1). Lastly, being a mangrove forest plant, Lumnitzera littorea is only found at sea level.
Furthermore, there may be cases where intercorrelations can explain some of the patterns. For example, bird pollination and altitude are correlated, as birds are important pollinators in many high-altitude tropical ecosystems (Cruden, 1972; Wolf \& Gill, 1986; Kessler \& Krömer, 2000). Similarly, it is likely that there is an intercorrelation between insularity and vertebrate pollination. Bird- and non-bird vertebrate pollination may be more prevalent on islands than in comparable mainland areas, due to a depauperate invertebrate pollinator fauna on islands (Elmqvist et al., 1992; Feinsinger, Wolfe \& Swarm, 1982; Olesen, 2003; Olesen \& Valido, 2003).

\section{(2) Coloured nectar and vertebrate pollination}

One straightforward interpretation of coloured nectar across all taxa is to see it as a visual floral cue to potential pollinators. In this study, we often find coloured nectar to be associated with observed or hypothesised ornithophily. Hence, it is tempting to interpret this floral trait as another example of visual floral adaptation to ornithophily. However, whether or not different floral traits fit neatly into clearly defined pollination syndromes has recently been the subject of debate, and some researchers have argued that syndromes are not very useful predictors of pollinators (reviewed by Fenster et al., 2004). Nevertheless, there are many studies that find syndromes to be valid and useful, at least to predict flower visitors or functional groups of most efficient pollinators at higher taxonomic levels (e.g. Bruneau, 1997; Lange, Scobell \& Scott, 2000; Temeles \& Kress, 2003; Hargreaves, Johnson \& Nol, 2004; Wilson et al., 2004). Fenster et al. (2004) conclude that pollination syndromes are of great use in understanding the ecology and evolution of plantpollinator interactions, and suggest that pollinators can be organised into functional groups according to the selection pressures they exert. Since many taxa with coloured nectar are visited by birds, or have been hypothesised to be visited by birds (Table 1), we can ask the question: do the observed nectar colours correspond to typical bird-colours of flowers? For yellow and especially orange and red, the answer is yes (e.g. Proctor et al., 1996). For darker nectar colours, especially black, the answer may also be yes if we substitute flower colour with fruit colour, as black is the most frequent fruit colour among bird-dispersed plant species in the tropics (Herrera, 2002; van der Pijl, 1982; Wheelwright \& Janson, 1985; Willson \& Whelan, 1990).

Furthermore, where known, most coloured nectars are hexose-dominated (Table 2), which could be an adaptation to generalised bird pollinators in habitats with a general dearth of pollinators, such as islands and montane areas (Cruden, 1972; Wolf \& Gill, 1986; Barrett, 1996; Olesen \& Jordano, 2002; Anderson, 2003). Generalised nectarfeeding birds often lack the specific enzymatic activity required to digest sucrose, and can thus only utilise the simpler hexose sugars (e.g. Martínez del Rio, Baker \& Baker, 1992).

Therefore, it is conceivable that several different generalised avian pollinators in insular or montane habitats can 
exert a relatively uniform selective pressure on one or more floral traits. For example, in the Canary Islands many unrelated plant lineages show a remarkable evolutionary flexibility in relation to nectar sugar composition. It has been hypothesised that this could be caused by selective pressures exerted by several generalist nectar-feeding passerine birds (Dupont et al., 2004).

However, birds are not the only vertebrates associated with coloured nectar. In Mauritius, at least one and possibly two or three Trochetia species are pollinated by endemic diurnal Phelsuma cepediana geckos (Hansen et al., in press), and two of the three Nesocodon mauritianus populations are found on cliffs, which harbour Phelsuma ornata geckos that are also well-known flower visitors (Nyhagen et al., 2001; Olesen et al., 2002), and which react strongly to coloured nectar as a visual signal for reward (Hansen et al., 2006). Furthermore, Phormium tenax in New Zealand is visited by endemic geckos, albeit nocturnal species. A recent review demonstrated that lizard pollination was almost exclusively an island phenomenon (Olesen \& Valido, 2003). Hence, further studies may reveal even more lizard pollinators for island plants with coloured nectar. Lastly, some coloured nectar plants are also visited and pollinated by nocturnal mammals (Table 1; Deplanchea tetraphylla, Fernandoa magnifica, Calliandra calothyrsus, Dombeya cacuminum and Banksia spp. and Trochetia triflora may have been pollinated by one of the two extinct small Mauritian fruitbat species, Pteropus subniger and $P$. rodricensis). While it is more difficult to envisage a visual function of coloured nectar during night, it may be related to diurnal pollinators for some of these species (D. tetraphylla, F. magnifica and Banksia spp.), or it may serve functions other than pollinator attraction or be a nonfunctional trait (see below).

\section{(3) Coloured nectar and insect pollination}

Obviously, coloured nectar could also function as a visual cue to flower visiting or pollinating insects. Small, insectpollinated flowers are probably even more unlikely to have had any colouration of their nectar documented than the relatively large flowers displayed by most of the plant species in our review. This could explain the bias towards large, vertebrate-pollinated flowers in our current knowledge of coloured nectar. We have a very incomplete knowledge of flower visitors for many of the plant species with coloured nectar, and some of the plants are likely to be mainly insect-pollinated (Hoya spp. and Capsicum spp.). These species are thus ideal candidates for studies investigating the potential functional significance of coloured nectar for insect pollinators or flower visitors.

\section{(4) Coloured nectar as an honest signal}

Thorp et al. (1975) suggested that the UV-reflectance of some nectars could be interpreted as a visual cue for flowervisiting insects, especially bees, allowing them to evaluate the presence and perhaps the abundance of nectar. Similarly, Weber \& Vogel (1986) suggested a functional significance of coloured nectar in the human visible spectrum. They interpreted the dark nectar against the yellow corolla in Deplanchea tetraphylla as a visual signal, a nectar guide, in addition to its primary function as a reward. Olesen et al. (1998) also suggested this link between signal and reward, and having observed birds visiting Nesocodon mauritianus, they speculated further that the coloured nectar could be interpreted not only as a visual cue, but additionally as an honest signal, leading to increased pollination efficiency (the idea was originally suggested to J. M. Olesen by W. S. Armbruster). However, they rejected this possibility, since - to their knowledge coloured nectar had not evolved in other regions and taxa. With our review we demonstrate that the opposite is true: coloured nectar has evolved independently and repeatedly in many geographical regions and in many plant taxa. This pattern of convergence suggests the possibility of a common selective pressure, such as the need for an honest signal (sensu Zahavi, 1975, 1977) to flower visitors, allowing them to judge the presence and size of the reward before flower visitation, and to adjust their behaviour accordingly.

Recently, another little-studied nectar trait, scent, was proposed to be a potential honest signal (Raguso, 2004b). $\mathrm{He}$ argued that scented nectar could facilitate remote detection of the nectar by potential pollinators, as well as providing an assessment of nectar quantity in individual flowers. A similar argument has been put forward in relation to the potential function of pollen odours by Dobson \& Bergström (2000), but they did not discuss the potential for honest signalling here. Scent may not always be a precise signal, as it strongly depends on environmental conditions. However, compared to visual signals that rely on an unobstructed straight line between sender and receiver, scent signals could be more efficient, as these can also be percieved without a straight line between sender and receiver. Additionally, some floral oils are known to be coloured (Buchmann \& Buchmann, 1981; Buchmann, 1987), and this could act as a visual honest signal in a parallel way to coloured nectar. Lastly, being a harvestable floral resource like nectar, pollen has also been shown to function as a visual signal (reviewed in Lunau, 2000), but unlike nectar, pollen in individual anthers is not a renewable floral resource. Once an anther has dehisced, it can produce no more pollen. However, temporal patterns of anther dehiscence during anthesis of individual flowers or inflorescences do provide a plant with some control over the amount of pollen available for harvest (Lunau, 2000). Hence, in some plant species, pollen may well function as an honest signal, too.

In general, for a signal to be honest, it has to infer some cost, a 'handicap', upon the signaller (Grafen, 1990; Zahavi, 1975; 1977). In coloured nectar plants, the cost can be at least twofold: firstly, colour compounds may be costly to produce. Here, the cost might be directly related to the production of the signal. However, until we have more knowledge on which processes or substances cause colouration of nectar, the biochemical cost of producing coloured nectar is impossible to calculate. Secondly, the cost can be seen as the number of visits that a flower does not receive when the nectar has been depleted and the signal is absent. In this scenario, contrary to conventional honest signalling theory, it is not the production or 
presence of a signal that is costly; it is rather the absence of the signal that is costly, as the flowers will not receive further visits until the signal has been replenished. Because signal and reward are coupled, an additional cost of having coloured nectar could be the loss of the plant's ability do deceive its pollinators and manipulate their movement patterns.

The benefit of coloured nectar to the pollinator is clear: it directs foraging towards rewarding flowers and promotes avoidance of visits to empty flowers, thus reducing foraging costs. The benefit to the plant is more complex. At first glance, coloured nectar could seem to be disadvantageous to the plants; penalising them because they receive fewer visits when the nectar is missing. However, as mentioned above, signal and reward are coupled in coloured nectar, and this could lead to rapid positive reinforcement of 'correct' pollinator behaviour. This would increase floral constancy, and hence also increase pollination efficiency. Furthermore, it is interesting to note that most of the plants with coloured nectar have inflorescences consisting of several to many flowers (e.g. Hoya spp., Aloe spp., Schwartzia brasiliensis, Leucosceptrum canum, Deplanchea tetraphylla, Schiedea spp., Dombeya spp., Grevillea spp., and Banksia spp.). Here, coloured nectar could facilitate a rapid orientation of the pollinators towards rewarding flowers 'in need of' pollen removal or pollen deposition. In turn, this would minimise geitonogamy, and lead to increased outcrossing (de Jong, Waser \& Klinkhamer, 1993). A parallel can be drawn to pollinators responding to colour changes in floral parts when flowers are no longer offering rewards; sometimes this colour change is even triggered by a pollinator visiting a flower and harvesting the rewards (Casper \& Pine, 1984; Weiss, 1991; Weiss, 1995 and references therein).

In many plants with coloured nectar the signal value of the nectar increases over time. That is, the longer a flower is not visited - and thus the nectar not harvested - the stronger the signal becomes, and in turn the flower might become more attractive to visitors. This can work in at least three different ways that are not mutually exclusive: firstly, in cases where the nectar is strongly coloured and easily seen - the larger the drops, the greater the reward and the stronger the attraction (e.g. Leucosceptrum canum, and Aloe, Faltomata and Hoya spp.). Secondly, the strength of the signal can increase with nectar volume. This is the case in Schiedea spp., where the nectar appears black only when a large drop has formed; in small amounts, or spread out thinly, it is a dirty grey and almost translucent (Weller et al., 1995; S. G. Weller personal communication). The same is true for Trochetia blackburniana, T. granulata and T. triflora where the yellow and amber colours of the nectar darken considerably against the corolla with increasing volume. Finally, the nectar colour can change over time. In some of the Hoya species, the nectar is initially secreted as a clear or almost clear liquid, which then changes into dark brown or red, perhaps as a result of oxidation (K. F. Yap, personal communication). The same process has been observed in some of the Aloe species (Johnson et al., 2006; Nicolson \& Nepi, 2005; Reynolds, 1940), in Faltomata biflora (Mione et al. 2001), in Banksia spp. (Markey
\& Lamont, 1995), and in some Deplanchea tetraphylla flowers (Weber \& Vogel, 1986).

However, it is not only the colour of the signal which is important - far more important could be the contrast between signal and background (Burns \& Dalen, 2002; Endler, 1992; Schmidt, Schaefer \& Winkler, 2004; Hansen et al., 2006). Why, then, do some species with coloured nectar also have strikingly coloured corollas, which could weaken the contrast between nectar and flower? We find this in Faltomata weberbaueri, where the corolla is a bright violet, in contrast to the pale colours in other Faltomata species with coloured nectar. A red corolla with yellow or red nectar is also seen in Trochetia boutoniana, T. uniflora and T. blackburniana. In these species, however, the base of the corolla is often much paler, thus providing a stronger contrast exactly where the nectar drops accumulate (Fig. 2G; Hansen et al., 2006). The same pattern is also seen in Aloe section Anguialoe. The most extreme case is perhaps Capsicum pubescens, where the corolla is almost entirely dark purple, except for five white spots near the centre - which is exactly where the yellow nectar accumulates into visible drops (Fig. 2P). The presence of conspicuous colours in both corolla and nectar may act in a complementary way (Raguso, 2004a). The coloured petals attract visitors from a distance and the coloured nectar then 'fine-tunes' visitor behaviour by guiding them to rewarding flowers. This may be especially important for plant species with large inflorescences with many flowers - which many coloured nectar plants have. Of course, another explanation is that the state is transitory, evolving towards colourful corollas with colourless nectar or vice versa.

Overall, these patterns could explain why coloured nectar has evolved repeatedly in habitats with a depauperate pollinator fauna, such as islands and montane areas, where competition for pollinators may be fierce. The relatively long 'shelf-life' of nectar in flowers in such habitats - i.e. potentially it is not 'harvested' that often may further increase the need to protect this resource against nectar thieves and microbial infestation (see below).

\section{(5) Other functions of coloured nectar}

Floral traits related to pollinator attraction may of course also attract herbivores or nectar robbers (Irwin, Adler \& Brody, 2004). Thus, pigments causing colouration of nectar could also be related to defensive or deterring functions, protecting the nectar crop against nectar-thieving ants (Galen, 1983; Stephenson, 1981, 1982), mites (Colwell, 1995), bees (Johnson et al., 2006; Irwin \& Brody, 1999) or long-billed nectar-robbing birds (Johnson et al., 2006). Coloured nectar could thus act as a double 'floral filter', keeping inefficient pollinators or nectar robbers at bay, while simultaneously serving as a visual signal for reward to legitimate pollinators and indeed, this is what Johnson et al. (2006) found to be the case for Aloe vryheidensis (see Section III.3.a). Another unusual nectar-based floral filter is found in Combretum lanceolatum (Combretaceae) from Brazil, where the nectar is presented in gelatinous drops that cannot be utilised by flower-visiting insects (Sazima et al., 2001). 
Lastly, colour pigments in nectar could serve as agents against microbial infestation (Janzen, 1977; Pichersky \& Gershenzon, 2002). Anti-microbial function has been demonstrated for proteins in floral nectars, especially against fungi that could spoil the nectar crop or attack the gynoecium (Carter \& Thornburg, 2004; Naqvi et al., 2005). Indeed, Olesen et al. (1998) found anti-bacterial properties in the aurone responsible for the red colouration of nectar in Nesocodon mauritianus. Also, all Melianthus species have very toxic vegetative parts, and extracts from leaves and stems of Melianthus comosus have been found to have anti-bacterial activity (Kelmanson, Jäger \& van Staden, 2000). While it seems that honey made from Melianthus nectar is not toxic to humans (Marloth, 1925), the nectar may still exhibit antibacterial properties. Future studies of coloured nectar should investigate potential anti-microbial properties by using bioassays or by screening for compounds with known anti-microbial properties - even though the latter approach could lead to non-detection of hitherto unknown compounds, or of compounds that may be common, but which are not easily screened (Adler, 2000).

The blood-red nectar of $\mathcal{N}$. mauritianus provides a cautionary tale: without any ecological evidence, Rosenkranz \& Klopman (1999) used a model-based approach to speculate further that the aurone responsible for the red colouration of $\mathcal{N}$. mauritianus nectar was a deterrent against endemic Mauritian mammalian nectar robbers. This cannot be the case, as there are no extant or extinct native non-flying mammals in Mauritius (Cheke, 1987a), and the endemic fruitbats - if they ever visited flowers that close to the ground - would most likely be efficient pollen vectors. This example stresses the importance of detailed regional ecological and natural history information when interpreting the potential functions of coloured nectar for a particular plant species. Generally, we need to be cautious in interpreting coloured nectar as adaptive per se, whether it is as a signal to attract or deter a certain group of flower-visiting animals, or as an anti-microbial function. We must evaluate each case based on field observations and experimental evidence on a species-by-species basis.

\section{(6) Non-functional explanations}

There are also non-functional explanations for the presence of coloured nectar is some species. For example, in Melianthus spp. and Schwartzia brasiliensis, the entire plant and the inflorescence, respectively, has dark pigmentation, and the dark colour of the nectar may simply be a nonadaptive or pleiotropic by-product of pigment biosynthesis elsewhere in the plant. A similar argument can be made for Puya alpestris, whose petals sport the same blue colour as the nectar, at least in plants grown in gardens, but we need more detailed studies of the plant and its nectar in the wild, where it may be darker and of a more red colouration (C. T. Hornung-Leoni, personal communication). Furthermore, it has recently been investigated how both herbivores and pollinators may select for nectar traits - that is, how traits that are related to both pollinator attractance and herbivore deterrence can be evolutionarily tightly linked (Adler \& Bronstein, 2004; Herrera et al., 2002) - and in some species coloured nectar could be an example of such correlated evolution. For Erythrina, the unusually high content of amino acids in the nectars of passerine-pollinated Erythrina species (Baker \& Baker, 1982) could account for the weak colouration of the nectar in the three species, but more investigations across the genus and across individual species' geographical ranges are needed. For Calliandra calothyrsus with nocturnal anthesis, it also seems unlikely that the yellow colour of the nectar has any function related to how pollinators perceive the flowers visually.

\section{(7) Evolution of coloured nectar}

The topology of the angiosperm phylogeny (Stevens, 2001 onwards) suggests that coloured nectar has evolved independently at the level of order at least 13 times (Fig. 3), and 15 times at the level of family (Table 1). For the majority of taxa with coloured nectar there are no species-level phylogenies available, and thus we cannot answer questions about single versus multiple origins of coloured nectar within these taxa, or speculate on when the trait arose within a lineage. One exception is Schiedea, where all four species with coloured nectar form a monophyletic group nested within a well-resolved phylogeny (Soltis et al., 1996; Weller et al., 1995; Wagner et al., 2005). In this case it is most parsimonious to assume that coloured nectar arose once within the clade, most likely in a species from Kaua'i, the older of the two islands where coloured nectar occurs. For Nesocodon mauritianus, recent molecular phylogenetic work shows it to be nested within the genus Heterochaenia with three species found on the neighbouring island of La Réunion (J. M. Olesen \& B. K. Ehlers, unpublished data). The flowers of $H$. ensifolia and $H$. rivalsii have clear nectar, but nectar colour is unknown in $H$. borbonica. Here, we can hypothesise a relatively recent origin of the evolution of coloured nectar, as La Réunion is approximately two million years old (McDougall, 1971). As Mauritius is about eight million years old (McDougall \& Chamalaun, 1969), it is thus most likely that $\mathcal{N}$. mauritianus is a recent addition to the Mauritian flora, and that coloured nectar evolved here after colonisation from La Réunion during a relatively short time.

Although no well-resolved species-level phylogenies exist for the other taxa with coloured nectar, it is still possible to make inferences about evolutionary events in some of the lineages. In Hoya, coloured nectar is found in all five species in the section Amblyostemma (Kloppenburg, 1994). This suggests that coloured nectar arose only once in Hoya. However, further phylogenetic studies are needed to confirm the monophyly of this section (Wanntorp et al., 2006, Wanntorp et al., in press). Similarly, the Banksia species with coloured nectar are all found in one group, Sphaerocarpa, in the series Abietinae (George, 1999). However, as our knowledge about nectar in this series is incomplete (Markey \& Lamont, 1995), and as there is no species-level phylogeny, we cannot deduce anything about single or multiple origins of coloured nectar. In Faltomata, Mione et al. (1994) constructed a phylogeny of parts of the 
genus, but only two species producing coloured nectar were included. These were members of an unresolved lineage, of which all other species produced clear nectar. Thus, no statement about single versus multiple origins of coloured nectar can be inferred here either. Mione \& Anderson (1996) speculated that if coloured nectar only evolved once in Faltomata, it could be seen as a key character. Together with long-distance bird dispersal of the brightly coloured berries, it could have fuelled an adaptive radiation of Faltomata species with coloured nectar into various habitats and altitudes.

Similarly, the evolution of black nectar in four Schiedea species could be seen as a novel way of attracting birds to provide outcrossing services. The four species with coloured nectar are all autogamous (self-pollinating) and in one case even cleistogamous (the flowers never open) (Weller et al., 1995). However, many other Schiedea species show very high levels of inbreeding depression (Culley et al., 1999; Norman et al., 1995; Rankin, Weller \& Sakai, 2002; Sakai, Karoly \& Weller, 1989; Sakai et al., 1997) and inbreeding depression was recently demonstrated for S. viscosa (Weller et al., 2005).

Some of the other taxa with coloured nectar are members of small genera (Capsicum, Leucosceptrum, Deplanchea, Schwartzia, Fernandoa, and Lumnitzera), where almost nothing is known about nectar colour in their respective congeners. Thus, in these cases it is also impossible to state anything about evolutionary events.

In summary, it is either known or suspected that coloured nectar has arisen only once in most lineages. It is not possible, however, to generalise on whether nectar colour is an evolutionarily labile or conservative floral trait. Contrary to the flexibility of floral morphology displayed within most angiosperm lineages, another nectar trait, sugar composition, has been considered a conservative trait (Baker \& Baker, 1983; Baker et al., 1998; Nicolson \& van Wyk, 1998; van Wyk \& Smith, 1996). Thus, we could assume nectar colour to be a conservative trait as well. However, a recent analysis of nectar sugar composition in putative ornithophilous species from the Canary Islands and their closest entomophilous relatives has demonstrated a remarkable evolutionary flexibility in sugar ratios (sucrose:hexose), possibly as a response to selective pressures from generalised avian pollinators (Dupont et al., 2004). Bruneau (1997) reported similar flexibility in sugar ratios and nectar amino acid concentrations in Erythrina (Fabaceae), both of which had changed repeatedly to reflect hummingbird- or passerine pollination, irrespectively of phylogenetic relationships. In general, it is thus possible to view nectar colour also as an evolutionarily labile trait, and to interpret shifts in nectar colour as being a result of selective pressures exerted by pollinators. However, phylogenetic inertia rather than continued selective pressures from pollinators could account for the persistence of coloured nectar once it has evolved in a lineage.

Obviously, for a pollinator to exert selective pressure on the colour of nectar, there must be variation in this floral trait in the first place. The vast majority of floral nectars are as clear as water. Therefore, one important question begs answering: how did the original variation in nectar colour in the species with coloured nectar arise? As discussed above, nectar may be coloured for several different reasons - or for no reason at all. Hence, any initial colouration of nectar may have been related to non-signalling functions or be purely pleiotropic in origin. At the moment, we know too little about the ecology and evolution of most taxa with coloured nectar. Only with several species- and lineagespecific studies can this question be addressed, and potential general trends investigated.

\section{CONGLUSIONS AND FUTURE DIREGTIONS}

(1) We have shown that coloured nectar is a widespread phenomenon, which is possibly correlated with one or more of several factors: vertebrate pollinators, insularity, and altitude. We believe that the occurrence of coloured nectar is even more widespread than this review suggests. However, coloured nectar is probably often overlooked by taxonomists describing new species, especially if the description is only based on herbarium material. We would thus like to call on workers in plant taxonomy, plant ecology and related fields to pay attention to coloured nectar in their study species and study areas. As shown, coloured nectar may be especially prevalent in vertebrate-pollinated, insular and/or montane taxa. Future reports of additional taxa with coloured nectar will enable us to investigate environmental and ecological correlates with more accuracy, as well as facilitate the testing of current hypotheses and development of new hypotheses on the function and evolution of this spectacular floral trait. With comparative methods, the evolution and maintenance of coloured nectar in lineages could be investigated - but species-level phylogenies are currently only available for a small number of lineages containing species with coloured nectar. Furthermore, future investigations of species with coloured nectar should aim to cover as much of a species' geographical range as possible; some species show variation in expression of nectar colour within a species, and only a broad sampling will elucidate the potential importance of local climatic and edaphic factors, and other nectar properties, such as $\mathrm{pH}$.

(2) Most importantly, there is a great need for experimental studies which address one or more of the hypotheses for the presence of colour pigments in nectar. In relation to the signalling hypothesis, we need studies of plants with coloured nectar and their interactions with flower visitors and pollinators, investigating whether coloured nectar can act as a visual cue and potentially as an honest signal. Experimental approaches could include manipulating nectar colour and amount in real or artificial flowers, and investigating the response of free-ranging or captive flower visitors (cf. Hansen et al., 2006; Johnson et al., 2006). Furthermore, future studies should include a biochemical analysis of the nectar to determine the identity of the pigments responsible for the colouration. There is also a need for experimental investigations of other functions of the colour pigments, especially as a defence against microbial infestation, and deterring of flower visitors that are inefficient pollinators or nectar robbers. Ultimately, to demonstrate adaptivity and fitness advantages of coloured nectar in relation to any ecological function, we need experiments in 
the field that assess the effect of coloured nectar on reproductive success - i.e. fruit- or seed set.

(3) Already, there is some experimental evidence that coloured nectar can have ecological functions: firstly, in the case of Aloe section Anguialoe, experiments show that the phenolics which impart the dark colouration of the nectar are distasteful to certain flower visitors that are morphologically unsuitable as pollinators, while at the same time visually attracting birds that are effective as pollinators (Johnson et al., 2006). Secondly, experiments with lizard pollinators in Mauritius show that they strongly prefer coloured nectar to clear nectar in artificial flowers (Hansen et al., 2006).

(4) A caveat in any study of coloured nectar as a visual signal is the 'perception space' (Chittka \& Brockmann, 2005) of the flower visitor species that may react to the presence of coloured nectar. Flower visitors are likely to perceive flower- and nectar colour differently to the way humans do, and interpretations of coloured nectar as a visual signal for a certain flower visitor should take the specific visual capabilities of that species into account. A good example of this is our inability to perceive colours in the UV range, whereas many insects, birds and lizards are able to perceive these colours. Hence, future research should also assess nectar colours in the UV range (Thorp et al., 1975). Moreover, as already mentioned, the contrast between colours rather than a preference for specific colours may be important (Hansen et al., 2006; Schmidt et al., 2004). Measurements of nectar and flower colours with a spectrometer (e.g. Ollerton et al., 2003) could be used to quantify colours in a 'perception space'-neutral manner, and comparisons of Euclidian distances (e.g. Schmidt et al., 2004) between flower and nectar colours thus obtained could be made to investigate the importance of colour identity versus contrast.

(5) In a review of sexual selection, Andersson \& Iwasa (1996) pointed out that sexual selection and signalling studies so far had been a major research area in zoology only, but that future studies could benefit from applying sexual selection and signalling theory in botany as well. Similarly, honest signalling in animals has been an active research area for a long time (see Maynard-Smith \& Harper, 2001 and references therein), but it has to our knowledge only been suggested three times previously in plants. Firstly, in relation to nectar scent (Raguso, 2004b) in parallel to our argument in this review. Secondly, in the positive correlation between floral bract size and resin award size in Dalechampia ipomoeifolia (Euphorbiaceae) blossoms, and how pollinating bees select flowers based on bract size rather than reward size (Armbruster, Antonsen $\&$ Pelabon, 2005). Interestingly, in relation to coloured versus clear nectar, Armbruster et al. (2005) speculate that while the resin in D. ipomoeifolia is clear, it is brightly coloured in many other Dalechampia species, and that coloured resin in those species could act as an honest signal without the need for additional honesty via bract size. Thirdly, honest signalling in plants has been proposed in the recent 'autumn colouration' hypothesis of Hamilton \& Brown (2001). This hypothesis states that the vibrant autumn leaf colours of deciduous trees are honest signals to deter phytophagous insects, and it has already created substantial debate and led to experimental approaches and calls for more research on colour patterns in plants in general (Atkinson, 2001; Holopainen \& Peltonen, 2002; Wilkinson et al., 2002; Hagen, Folstad \& Jakobsen, 2003; Schaefer \& Wilkinson, 2004; Archetti \& Leather, 2005; Schaefer \& Rolshausen, 2006). Furthermore, compared to signalling between animals, signals from plants to animals lend themselves well to study, due to a relative constancy in time and space, and a lower complexity and simpler dynamics (Schaefer, Schaefer \& Levey, 2004). We propose that plants with coloured nectar and their flower visitors are an excellent study system to investigate honest signalling in plants. Comparative studies in a phylogenetic framework of species with and without coloured nectar would be particularly useful, addressing both ecological and evolutionary aspects of coloured nectar.

(6) In summary, future research on coloured nectar has the potential not only to increase our basic knowledge about this fascinating floral trait, but also to contribute significantly to the diverse fields of signalling theory, nectar biochemistry, pollination biology and the evolutionary ecology of mutualisms.

\section{AGKNOWLEDGEMENTS}

We would like to thank the following people in particular for invaluable help during the long gestation time of this work; for providing information, photos, unpublished data, and/or obscure references: W. Barthlott, A. Boatman, C. Burton, J. R. Chamberlain, J. Christiansen, H. Davis, W.H. Esbaugh, A. Flower, F. Forest, P. Forster, L. Gigord, H. F. Glen, M. Heads, P. B. Heenan, J. Henning, C. T. Hornung-Leoni, K. Jensen, P. Jones, C. N. Kaiser, C. Keena, B. Kemble, R. D. Kloppenburg, T. Krömer, B. B. Lamont, S. Leiva G., D. J. Liddle, H. P. Linder, B. Loison, J. C. Machuca, R. O. Makinson, S. W. Nicolson, T. H. Nielsen, M. V. Norup, T. Nyhuus, J. Ollerton, R. G. Olmstead, R. Pettersson, D. Poole, G. M. Pradhan, C. Puff, R. A. Raguso, D. L. Roberts, M. Rocca, I. \& M. Sazima, G. Sankowsky, J. Shykoff, H. Skovgaard, R. W. Thorp, P. B. Tomlinson, D. R. Towns, R. G. Turner, A. Valido, L. van Kradenburg, P. Walin, L. Wanntorp, A. Weber, S. G. Weller, B.-E. van Wyk, P. Wyse Jackson, L. Yacher and K. F. Yap. The manuscript was greatly improved by critical comments and helpful suggestions on earlier drafts by Y. L. Dupont, T. C. Good, S. W. Nicolson, R. A. Raguso, H. M. Schaefer and two anonymous reviewers. Financial support was received from the Swiss National Science Foundation (grant no. 631-065950 to C. B. M.) and from the Carlsberg Foundation and the Danish Natural Research Council (to J. M. O.).

\section{REFERENGES}

Adler, L. S. (2000). The ecological significance of toxic nectar. Oikos 91, 409-420.

Adler, L. S. \& Bronstein, J. H. (2004). Attracting antagonists: Does floral nectar increase herbivory? Ecology 85, 1519-1526. 
Anderson, S. H. (2003). The relative importance of birds and insects as pollinators of the New Zealand flora. New Zealand Fournal of Ecology 27, 83-94.

Andersson, M. \& Iwasa, Y. (1996). Sexual selection. Trends in Ecology and Evolution 11, 53-58.

Archer, R. H. \& Condy, G. (1997). Melianthus pectinatus subsp. gariepinus. Flowering Plants of Africa 55, 82-85.

Archetti, M. \& Leather, S. R. (2005). A test of the coevolution theory of autumn colours: colour preference of Rhopalosiphum padi on Prunus padus. Oikos 110, 339-343.

Armbruster, W. S., Antonsen, L. \& Pelabon, C. (2005). Phenotypic selection on Dalechampia blossoms: Honest signaling affects pollination success. Ecology 86, 3323-3333.

AtKinson, N. (2001). Out on a limb, or a new branch of signalling theory? Trends in Ecology and Evolution 16, 603.

Avé, W. (1984). Deplanchea. Pacific Plant Areas 4, 152-153.

BAKER, H. G. \& BAKER, I. (1973). Amino-acids in nectar and their evolutionary significance. Nature 241, 543-545.

Baker, H. G. \& BAKer, I. (1983). Floral nectar sugar constituents in relation to pollinator type. In Handbook of Pollination Biology, pp. 117-141.

Baker, H. G. \& Baker, I. (1986). The occurrence and significance of amino-acids in floral nectar. Plant Systematics and Evolution 151, 175-186.

BAKer, H. G. \& BAKer, I. (1990). The predictive value of nectar chemistry to the recognition of pollinator types. Israel fournal of Botany 39, 157-166.

Baker, H. G., Baker, I. \& Hodges, S. A. (1998). Sugar composition of nectars and fruits consumed by birds and bats in the tropics and subtropics. Biotropica 30, 559-586.

BAKer, I. \& BAKer, H. G. (1982). Some chemical constituents of floral nectars of Erythrina in relation to pollinators and systematics. Allertonia 3, 25-37.

Barrett, S. C. H. (1996). The reproductive biology and genetics of island plants. Philosophical Transactions of the Royal Society London B 351, 725-733.

Becerra, J. X. \& Lloyd, D. G. (1992). Competition-dependent abscission of self-pollinated flowers of Phormium tenax (Agavaceae): A 2nd action of self-incompatibility at the whole flower level? Evolution 46, 458-469.

BitTer, G. (1921). Solanaceae - Potato family. Repertorium Specierum Novarum Regni Vegetabilis 17, 338-346.

Bitter, G. (1924). Eine Synonymierung. Hebecladus umbellatus. Feddes Repertorium 20, 375-376.

Brown, E. D. \& Hopkins, M. J. G. (1995). A test of pollinator specificity and morphological convergence between nectarivorous birds and rainforest tree flowers in New Guinea. Oecologia 103, 89-100.

Bruneau, A. (1996). Phylogenetic and biogeographical patterns in Erythrina (Leguminosae: Phaseoleae) as inferred from morphological and chloroplast DNA characters. Systematic Botany 21, 587-605.

Bruneau, A. (1997). Evolution and homology of bird pollination syndromes in Erythrina (Leguminosae). American Fournal of Botany 84, 54-71.

Buchmann, S. L. (1987). The ecology of oil flowers and their bees. Annual Review of Ecology and Systematics 18, 343-369.

Buchmann, S. L. \& Buchmann, M. D. (1981). Anthecology of Mouriri myrtilloides (Melastomataceae, Memecyleae), an oil flower in Panama. Biotropica 13, 7-24.

Burns, K. C. \& Dalen, J. L. (2002). Foliage color contrasts and adaptive fruit color variation in a bird-dispersed plant community. Oikos 96, 463-469.
Gainuan, H., Siyi, O., Liang, F., Yong, W., Ning, Z., Zhijie, Q. \& Guojun, H. (2004). Study on extraction and stability of pigment from flowers of Leucosceptrum canum (Article in Chinese). Zhong Yao Cai 27, 243-246.

Garter, C. \& Thornburg, R. W. (2004). Is the nectar redox cycle a floral defense against microbial attack? Trends in Plant Science $\mathbf{9}$, 320-324.

Carthew, S. M. \& Goldingay, R. L. (1997). Non-flying mammals as pollinators. Trends in Ecology \& Evolution 12, 104-108.

Gasper, B. B. \& Pine, T. R. L. (1984). Changes in corolla color and other floral characteristics in Cryptantha humilis (Boraginaceae): Cues to discourage pollinators? Evolution 38, 128-141.

Chamberlain, J. R. (1998). Isyzyme variation in Calliandra calothyrsus (Leguminosae): Its implications for species delimitation and conservation. American Fournal of Botany 85, 37-47.

Chamberlain, J. R. (2000). Improving seed production in Calliandra calothyrsus. A field manual for researchers and extension workers. Oxford Forestry Institute, Oxford UK.

Cheke, A. S. (1987a). An ecological history of the Mascarene Islands, with particular reference to extinctions and introductions of land vertebrates. In Studies of Mascarene Island birds (ed. A. W. Diamond), pp. 5-89. Cambridge University Press, Cambridge.

Cheke, A. S. (1987b). The ecology of the smaller land birds of Mauritius. In Studies of Mascarene Island birds (ed. A. W. Diamond), pp. 151-207. Cambridge University Press, Cambridge.

Cheke, R. A. \& Mann, C. F. (2001). Sunbirds: a Guide to the Sunbirds, Flowerpeckers, Spiderhunters and Sugarbirds of the World. Christopher Helm, London.

Chittka, L. \& Brockmann, A. (2005). Perception space - the final frontier. PLoS Biology 3, el37.

Colwell, R. K. (1995). Effects of nectar consumption by the hummingbird flower mite Proctolaelaps kirmsei on nectar availability in Hamelia patens. Biotropica 27, 206-217.

Court, D. (1981). Succulent flora of Southern Africa. A.A. Balkema, Rotterdam.

Cowan, A. M. \& Cowan, J. M. (1929). The trees of Northern Bengal. Bengal Secretariat Book Depot, Calcutta.

Craig, J. L. \& Stewart, A. M. (1988). Reproductive biology of Phormium tenax - a honeyeater-pollinated species. New Zealand Journal of Botany 26, 453-463.

Cruden, R. W. (1972). Pollinators in high-elevation ecosystems relative effectiveness of birds and bees. Science 176, 1439-\&.

Gulley, T. M., Weller, S. G., Sakai, A. K. \& Rankin, A. E. (1999). Inbreeding depression and selfing rates in a selfcompatible, hermaphroditic species, Schiedea membranacea (Caryophyllaceae). American fournal of Botany 86, 980-987.

Dale, I. R. \& Greenway, P. J. (1961). Kenya trees and shrubs. Buchanan Estates, Nairobi.

De Jong, T. J., Waser, N. M. \& Klinkhamer, P. G. L. (1993). Geitonogamy - the neglected side of selfing. Trends in Ecology $\mathcal{E}^{\circ}$ Evolution 8, 321-325.

De Roon, A. C. \& Dressler, S. (1997). New taxa of Norantea Aubl. s.l. (Marcgraviaceae) from Central America and adjacent South America. Bot. Jahrb. Syst. 119, 327-335.

Dillon, M. O. (1997). Lomas formations: Peru. In The Americas, vol. 3. Centres of Plant Diversity, A guide and strategy for their conservation (ed. S. D. Davis et al.), pp. 519-527. The World Wide Fund for Nature and IUCN - The World Conservation Union, Oxford, UK.

Dobson, H. E. M. \& Bergström, G. (2000). The ecology and evolution of pollen odors. Plant Systematics and Evolution 222, 63-87.

Dortort, F. (2003). Pineapples. Succulent of the Month, July 2003. University of California Botanical Garden. http:// 
ucbgdev.berkeley.edu/SOM/SOM-pineapples.shtml (accessed January 2006).

Dressler, S. (2004). Marcgraviaceae. In The Families and Genera of Vascular Plants, vol. 6 (ed. K. Kubitzki), pp. 258-265. Springer, Berlin.

Dupont, Y. L., Hansen, D. M., Rasmussen, J. T. \& Olesen, J. M. (2004). Evolutionary changes in nectar sugar composition associated with switches between bird and insect pollination: the Canarian bird-flower element revisited. Functional Ecology 18, 670-676.

Dyer, A. G. (1931). Aloe sessiliflora. Flowering Plants of South Africa 11, Plate 435.

Dyer, A. G. (1941). Aloe vryheidensis. Flowering Plants of South Africa 21, Plate 805.

Dyer, R. A. (1952). Melianthus villosus. Flowering Plants of Africa 29, Plate 1140.

Ehlers, B. K. \& Olesen, J. M. (1997). The fruit-wasp route to toxic nectar in Epipactis orchids? Flora 192, 1-7.

Elmovist, T., Cox, P. A., Rainey, W. E. \& Pierson, E. D. (1992). Restricted pollination on oceanic islands - pollination of Ceiba pentandra by flying foxes in Samoa. Biotropica 24, 15-23.

ENDLER, J. A. (1992). Signals, signal conditions, and the direction of evolution. American Naturalist 139, S125-S153.

Endress, P. K. (1994). Diversity and evolutionary biology of tropical flowers. Cambridge University Press, Cambridge.

Estolas, W. (2004). Green honey produced in 'marijuana capital'. In Manila Times, 18. June.

Feinsinger, P., Wolfe, J. A. \& Swarm, L. A. (1982). Island ecology: Reduced hummingbird diversity and the pollination biology of plants, Trinidad and Tobago, West Indies. Ecology 63, 494-506.

Fenster, G. B., Armbruster, W. S., Wilson, P., Dudash, M. R. \& Thomson, J. D. (2004). Pollination syndromes and floral specialization. Annual Review of Ecology Evolution and Systematics 35, 375-403.

Forster, P. I. (1992). Pollination of Hoya australis (Asclepiadaceae) by Ocybadistes walkeri sothis (Lepidoptera: Hesperidae). Australian Entomological Magazine 19, 39-43.

Forster, P. I., Liddle, D. J. \& Liddle, I. M. (1998). Diversity in the genus Hoya (Asclepiadaceae - Marsdenieae). Aloe 35, 44-48.

Friedmann, F. (1987). 53. Sterculiacées. In Flore des Mascareignes, vol. 51-62 (ed. J. Bosser, T. Cadet, J. Guého and W. Marais), pp. 150. The Sugar Industry Research Institute, Réduit, Mauritius.

Fris, I. \& Bidgood, S. (1998). Dombeya kefaensis, sp. nov. (Sterculiaceae) from SW Ethiopia. Nordic Fournal of Botany 18, 215-220.

Galen, C. (1983). The effect of nectar-thieving ants on seedset in floral scent morphs of Polemonium viscosum. Oikos 41, 245-249.

Gardener, M. C. \& Gillman, M. P. (2002). The taste of nectar a neglected area of pollination ecology. Oikos 98, 552-557.

George, A. S. (1999). Banksia. In Flora of Australia, vol. 17B, pp. 175-250. ABRS/CSIRO, Melbourne.

Gigord, L., Lavigne, C. \& Shykoff, J. A. (1998). Partial selfincompatibility and inbreeding depression in a native tree species of La Reunion (Indian Ocean). Oecologia 117, 342-352.

Gigord, L., Picot, F. \& Shykoff, J. A. (1999). Effects of habitat fragmentation on Dombeya acutangula (Sterculiaceae), a native tree on La Reunion (Indian Ocean). Biological Conservation 88, 43-51.

GILL, F. B. (1971). Ecology and evolution of the sympatric Mascarene White-eyes, Zosterops borbonica and Zosterops olivacea. Auk 88, 36-60.

Givnish, T. J., Millam, K. C., Evans, T. M., Hall, J. C., Pires, J. C., Berry, P. E. \& Sytsma, K. J. (2004). Ancient vicariance or recent long-distance dispersal? Inferences about phylogeny and South American-African disjunctions in rapateaceae and bromeliaceae based on ndhF sequence data. International fournal of Plant Sciences 165, S35-S54.

Glen, H. F. \& Hardy, D. S. (1995). Aloe section Anguialoe and the problem of Aloe spicata LF (Aloaceae). Haseltonia 3, 92-103.

Gottsberger, G., Schraumen, J. \& Linskens, H. F. (1984). Amino acids and sugars in nectar, and their putative evolutionary significance. Plant Systematics and Evolution 145, 55-77.

Gourlay, W. B. (1950). Puya alpestris in its native land. Fournal of the Royal Horticultural Society 75, 399-402.

GrafEN, A. (1990). Biological signals as handicaps. Fournal of Theoretical Biology 144, 517-546.

Groenewald, B. H. (1938). Beskrywing van 'n nuwe Aloe uit Noord-Transvaal. Tydskrif vir Wetenskap en Kuns August, 178-181.

Guillarmod, A. J., Jubb, R. A. \& Skead, C. J. (1979). Field studies of six Southern African species of Erythrina. Annals of the Missouri Botanical Garden 66, 521-527.

Hagen, S. B., Folstad, I. \& Jakobsen, S. W. (2003). Autumn colouration and herbivore resistance in mountain birch (Betula pubescens). Ecology Letters 6, 807-811.

Hamilton, W. D. \& Brown, S. P. (2001). Autumn tree colours as a handicap signal. Proceedings of the Royal Society of London Series B Biological Sciences 268, 1489-1493.

Hansen, D. M., Beer, K. \& Müller, C. B. (2006). Mauritian coloured nectar no longer a mystery: a visual signal for lizard pollinators. Biology Letters 2, 165-168.

Hansen, D. M., Kiesbüy, H. C., Jones, C. G. \& Müller, C. B. (in press). Positive indirect interactions between neighbouring plant species via a lizard pollinator. American Naturalist.

Hansen, D. M., Olesen, J. M. \& Jones, C. G. (2002). Trees, birds and bees in Mauritius: exploitative competition between introduced honey bees and endemic nectarivorous birds? Fournal of Biogeography 29, 721-734.

Hargreaves, A. L., Johnson, S. D. \& Nol, E. (2004). Do floral syndromes predict specialization in plant pollination systems? An experimental test in an "ornithophilous" African Protea. Oecologia 140, 295-301.

Herrera, C. M. (2002). Seed dispersal by vertebrates. In Plantanimal interactions (ed. C. M. Herrera and O. Pellmyr), pp. 185208. Blackwell, Oxford.

Herrera, C. M., Medrano, M., Rey, P. J., Sanchez-Lafuente, A. M., Garcia, M. B., Guitian, J. \& Manzaneda, A. J. (2002). Interaction of pollinators and herbivores on plant fitness suggests a pathway for correlated evolution of mutualism- and antagonism-related traits. Proceedings of the National Academy of Sciences 99, 16823-16828.

Hesselius, A. (1785). Dissertatio de Aloe. Dissertationes Academicae Upsaliae Habitae 2, 181-194.

Holopainen, J. K. \& Peltonen, P. (2002). Bright autumn colours of deciduous trees attract aphids: nutrient retranslocation hypothesis. Oikos 99, $184-188$.

Hornung-Leoni, G. \& Sosa, V. (2004). Filogenia morphológica de Puya subgénero Puya (Bromeliaceae). Primera Reunión Mexicana de Biología Filogenética, Xalapa, Abstract.

Hornung-Leoni, G. \& Sosa, V. (2006). Morphological variation in Puya (Bromeliaceae): an allometric study. Plant Systematics and Evolution 256, 35-53.

Humeau, L. \& Thompson, J. D. (2001). The allometry of flower size dimorphism in dioecious Dombeya species on La Réunion. Ecology Letters 4, 221-228.

Irwin, R. E., Adler, L. S. \& Brody, A. K. (2004). The dual role of floral traits: Pollinator attraction and plant defense. Ecology 85, 1503-1511. 
IRwIN, R. E. \& BRody, A. K. (1999). Nectar-robbing bumble bees reduce the fitness of Ipomopsis aggregata (Polemoniaceae). Ecology 80, 1703-1712.

Jackson, S. M. (2001). Foraging behaviour and food availability of the mahogany glider Petaurus gracilis (Petauridae: Marsupialia). Fournal of Zoology 253, 1-13.

JANZEN, D. H. (1977). Why fruits rot, seeds mold and meat spoils. American Naturalist 111, 691-713.

Jensen, K. (2005). Generalisation and specialisation in tropical pollination systems. MSc thesis, University of Aarhus.

Johow, F. (1898). Über Ornithophilie in der chilenischen Flora. Sitzungsberichte der Preussischen Akademie der Wissenschaften zu Berlin 28, 332-341.

Johnson, S. D, Hargreaves, A. L. \& Brown, M. (2006). Dark bitter-tasting nectar functions as a filter of flower visitors in a bird-pollinated plant. Ecology.

Kalinganire, A., Harwood, C. E., Sleee, M. U. \& Simons, A. J. (2001). Pollination and fruit-set of Grevillea robusta in western Kenya. Austral Ecology 26, 637-648.

Kelmanson, J. E., Jäger, A. K. \& van Staden, J. (2000). Zulu medicinal plants with antibacterial activity. Fournal of Ethnopharmacology 69, 241-246.

Kessler, M. \& Krömer, T. (2000). Patterns and ecological correlates of pollination modes among bromeliad communities of Andean forests in Bolivia. Plant Biology 2, 659-669.

Kleijn, D. \& van DonkelaAr, R. (2001). Notes on the taxonomy and ecology of the genus Hoya (Asclepiadaceae) in Central Sulawesi. Blumea 46, 457-483.

Kloppenburg, D. (1994). Hoya sections. Fraterna, 1st \& 2nd Quarters, pp. I-XXIV.

Knudsen, J. T. \& Tollsten, L. (1995). Floral scent in batpollinated plants - a case of convergent evolution. Botanical Fournal of the Linnean Society 119, 45-57.

Krukoff, B. A. \& Barneby, R. C. (1974). Conspectus of species of the genus Erythrina. Lloydia 34, 332-459.

Lamont, B. B. (1980). Blue-green algae in nectar of Banksia aff. sphaerocarpa. The Western Australian Naturalist 14, 193-194.

Lange, R. S., Scobell, S. A. \& Scott, P. E. (2000). Hummingbirdsyndrome traits, breeding system, and pollinator effectiveness in two syntopic Penstemon species. International Fournal of Plant Sciences 161, 253-263.

Li, H. W. \& Hedge, I. C. (1994). 73. Leucosceptrum. In Flora of China. Vol. 17 (Verbenaceae to Solanaceae) (ed. Z. Wu and P. H. Raven), pp. 342. Science Press \& Missouri Botanical Garden, St. Louis.

LLAMAS, K. A. (2003). Tropical flowering plants: a guide to identification and cultivation. Timber Press, Cambridge.

Lunau, K. (2000). The ecology and evolution of visual pollen signals. Plant Systematics and Evolution 222, 89-111.

Mabberley, D. J. (1997). The plant book. Cambridge University Press, Cambridge.

Makinson, R. O. (2000). Grevillea. In Flora of Australia, vol. 17A. ABRS/CSIRO Publishing, Melbourne.

Mann, H. (1866). Revision of the genus Schiedea and of the Hawaiian Rutaceae. Proceedings of the Boston Society of Natural History 10, 309-319.

Markey, A. S. \& Lamont, B. B. (1995). The potential for cyanobacterial nitrogen fixation in the floral nectar of certain Banksias, pp. 33. Botany Department, University of Western Australia. School of Environmental Biology, Curtin University of Technology, Perth.

Marloth, R. (1925). The Flora of South Africa. Families 61-106. Darter Bros. \& Co., Capetown.
Martínez Del Rio, C., Baker, H. G. \& Baker, I. (1992). Ecological and evolutionary implications of digestive processes bird preferences and the sugar constituents of floral nectar and fruit pulp. Experientia 48, 544-550.

Maynard-Smith, J. \& Harper, D. (2001). Animal signals. Oxford University Press, Oxford.

Mcdougall, I. (1971). The geochronology and evolution of the young volcanic island of Réunion, Indian Ocean. Geochimica et Cosmochimica Acta 35, 261-288.

Mcdougall, I. \& Chamalaun, F. H. (1969). Isotopic dating and geomagnetic polarity studies on volcanic rocks from Mauritius, Indian Ocean. Geological Society of America Bulletin 80, 1419-1442.

Mione, T. \& Anderson, G. J. (1996). Faltomata: an introduction, and preliminary observations on the red/orange floral nectar. Solanaceae Newsletter 4, 51-57.

Mione, T., Mugaburu, D. \& Connolly, B. (2001). Rediscovery and floral biology of Jaltomata biflora (Solanaceae). Economic Botany 55, 167-168.

Mione, T., Olmstead, R. G., Jansen, R. K. \& Anderson, G. J. (1994). Systematic implications of chloroplast DNA variation in faltomata and selected physaloid genera (Solanaceae). American Fournal of Botany 81, 912-918.

Muchinala, N. (2003). Exploring the boundary between pollination syndromes: bats and hummingbirds as pollinators of Burmeistera cyclostigmata and B. tenuiflora (Campanulaceae). Oecologia 134, 373-380.

Naqvi, S. M. S., Harper, A., Carter, C., Ren, G., Guirgis, A., York, W. S. \& Thornburg, R. W. (2005). Nectarin IV, a potent endoglucanase inhibitor secreted into the nectar of ornamental tobacco plants. Isolation, cloning and characterization. Plant Physiology 139, 1389-1400.

Nicolson, S. W. (1993). Low nectar concentrations in a dry atmosphere - a study of Grevillea robusta (Proteaceae) and Callistemon viminalis (Myrtaceae). South African Fournal of Science 89, 473-477.

Nicolson, S. W. (1995). Direct demonstration of nectar reabsorption in the flowers of Grevillea robusta (Proteaceae). Functional Ecology 9, 584-588.

Nicolson, S. W. \& NePI, M. (2005). Dilute nectar in dry atmospheres: nectar secretion patterns in Aloe castanea (Asphodelaceae). International fournal of Plant Sciences 166, 227-233.

Nicolson, S. W. \& VAN WyK, B.-E. (1998). Nectar sugars in Proteaceae: patterns and processes. Australian Fournal of Botany 46, 489-504.

Norman, J. K., Sakai, A. K., Weller, S. G. \& Dawson, T. E. (1995). Inbreeding depression in morphological and physiological traits of Schiedea lydgatei (Caryophyllaceae) in 2 environments. Evolution 49, 297-306.

Nyhagen, D. F., Kragelund, C., Olesen, J. M. \& Jones, G. G. (2001). Insular interactions between lizards and flowers: flower visitation by an endemic Mauritian gecko. Fournal of Tropical Ecology 17, 755-761.

Olesen, J. M. (2003). Island pollinators. In Island ecosystems: Conservation and molecular approach (ed. M. A. A. P. d. Carvalho, G. P. Costa, J. A. Jesus and D. M. M. Rodrigues), pp. 45-86. Centre of Biological and Geological Sciences, Funchal.

Olesen, J. M., Eskildsen, L. I. \& Venkatasamy, S. (2002). Invasion of pollination networks on oceanic islands: importance of invader complexes and endemic super generalists. Diversity and Distributions 8, 181-192.

Olesen, J. M., \& Jordano, P. (2002). Geographic patterns in plantpollinator mutualistic networks. Ecology 83, 2416-2424. 
Olesen, J. M., Rønsted, N., Tolderlund, U., Cornett, C., Mølgaard, P., Madsen, J., Jones, G. G. \& Olsen, C. E. (1998). Mauritian red nectar remains a mystery. Nature 393, 529.

Olesen, J. M. \& Valido, A. (2003). Lizards as pollinators and seed dispersers: an island phenomenon. Trends in Ecology E् Evolution 18, 177-181.

Ollerton, J. \& Liede, S. (1997). Pollination systems in the Asclepiadaceae: a survey and preliminary analysis. Biological Fournal of the Linnean Society 62, 593-610.

Ollerton, J., Johnson, S. D., Granmer, L. \& Kellie, S. (2003). The pollination ecology of an assemblage of grassland asclepiads in South Africa. Annals of Botany 92, 807-834.

Ortiz-Crespo, F. I. (1973). Field studies on pollination of plants of the genus Puya. Fournal of the Bromeliad Society 23, 3-7 \& 54-58.

Palmer, B., Macqueen, D. J. \& Gutteridge, R. C. (1994). Calliandra calothyrsus - a multipurpose tree legume for humid locations. In Forage tree legumes in tropical agriculture (ed. R. C. Gutteridge and H. M. Shelton), pp. 65-74. CAB International, Wallingford UK.

Pauw, A. (1998). Pollen transfer on birds' tongues. Nature 394, 731732.

Percival, M. S. (1961). Types of nectar in angiosperms. New Phytologist 60, 235-281.

Pichersky, E. \& Gershenzon, J. (2002). The formation and function of plant volatiles: perfumes for pollinator attraction and defense. Current Opinion in Plant Biology 5, 237-243.

Pinheiro, M. C. B., Ormond, W. T., De Lima, H. A. \& Correia, M. C. R. (1995). Biology of reproduction of Norantea brasiliensis Choisy (Marcgraviaceae). Revista Brasileira de Biologia 55(Suppl. 1), 79-88.

Pole Evans, I. B. (1925). Aloe sessiliflora. Flowering Plants of South Africa 5, Plate 180.

Prenner, G. (2002). Secondary pollen presentation on petals of Dombeya cacuminum Hochr. (Sterculiaceae). Stapfia 80, 323-326.

Proctor, M., Yeo, P. \& Lack, A. (1996). The natural history of pollination. Timber Press, Portland.

Raguso, R. A. (2004a). Flowers as sensory billboards: progress towards an integrated understanding of floral advertisement. Current Opinion in Plant Biology 7, 434-440.

Raguso, R. A. (2004b). Why are some floral nectars scented? Ecology 85, 1486-1494.

Rankin, A. E., Weller, S. G. \& Sakai, A. K. (2002). Mating system instability in Schiedea menziesii (Caryophyllaceae). Evolution 56, $1574-1585$.

Raven, P. H. (1974). Eryhthrina (Fabaceae): Achievements and opportunities. Lloydia 37, 321-331.

Reynolds, G. W. (1940). Genus Aloe: A new section and a new series. Fournal of South African Botany 6, 111-116.

Richardson, I. B. K. (1979). Nesocodon mauritianus. Kew Bulletin 33, 547-550.

Rocca, M. A., Sazima, M. \& Sazima, I. (in press). Woody woodpecker enjoys soft drinks: the blond-crested woodpecker seeks nectar and pollinates canopy plants in south-eastern Brazil. Biota Neotropica.

Ronse Decraene, L. P., Linder, H. P., Dlamini, T. \& Smets, E. F. (2001). Evolution and development of floral diversity of Melianthaceae, an enigmatic Southern African family. International Fournal of Plant Sciences 162, 59-82.

Rosenkranz, H. S. \& Klopman, G. (1999). The mysterious Mauritian red nectar: A selective toxicant? Naturwissenschaften $\mathbf{8 6}$, $404-405$.
Ruiz, H. \& Pavón, J. (1799). Florae Peruvianae et Chilensis, vol. 2. SAFFord, R. J. (1991). Status and ecology of the Mauritius Fody Foudia rubra and Mauritius Olive White-eye Zosterops chloronothos: two Mauritian passerines in danger. Dodo 27, 113-139.

Sakai, A. K., Karoly, K. \& Weller, S. G. (1989). Inbreeding depression in Schiedea globosa and Schiedea salicaria (Caryophyllaceae), subdioecious and gynodioecious Hawaiian species. American Journal of Botany 76, 437-444.

Sakai, A. K., Weller, S. G., Chen, M. L., Chou, S. Y. \& Tasanont, C. (1997). Evolution of gynodioecy and maintenance of females: The role of inbreeding depression, outcrossing rates, and resource allocation in Schiedea adamantis (Caryophyllaceae). Evolution 51, 724-736.

Sazima, I., Buzato, S. \& Sazima, M. (1993). The bizarre inflorescence of Norantea brasiliensis (Marcgraviaceae): visits of hovering and perching birds. Botanica Acta 106, 507-513.

SAzima, M., SAzima, I. \& Buzato, S. (1994). Nectar by day and night: Siphocampylus sulfereus (Lobeliaceae) pollinated by hummingbirds and bats. Plant Systematics and Evolution 191, 237-246.

Sazima, I., SAzima, C. \& Sazima, M. (2005). Little dragons prefer flowers to maidens: a lizard that laps nectar and pollinates trees. Biota Neotropica 5, BN00805012005, http://www.biotaneotropica.org.br/v5nl/pt/fullpaper?bn00805012005+en.

Sazima, M., Vogel, S., do Prado, A. L., de Oliveira, D. M., Franz, G. \& Sazima, I. (2001). The sweet jelly of Combretum lanceolatum flowers (Combretaceae): a cornucopia resource for bird pollinators in the Pantanal, western Brazil. Plant Systematics and Evolution 227, 195-208.

Schaefer, H. M. \& Rolshausen, G. (2006). Plants on red alert: do insects pay attention? Bioessays 28, 65-71.

Schaefer, H. M., Schaefer, V. \& Levey, D. J. (2004). How plantanimal interactions signal new insights in communication. Trends in Ecology \& Evolution 19, 577-584.

Schaefer, H. M. \& Wilkinson, D. M. (2004). Red leaves, insects and coevolution: a red herring? Trends in Ecology E Evolution 19, 616-618.

Schmidt, V., Schaefer, H. M. \& Winkler, H. (2004). Conspicuousness, not colour as foraging cue in plant-animal signalling. Oikos 106, 551-557.

Scogin, R. (1985). Floral anthocyanins in the genus Puya. Biochemical Systematics and Ecology 13, 387-389.

Scogin, R. \& Freeman, C. E. (1984). Floral pigments and nectar constituents in the genus Puya (Bromeliaceae). ALISO 10, 617-619.

Scott-Elliot, G. F. (1890). Ornithophilous flowers in South Africa. Annals of Botany 4, 265-280.

Seyani, J. H. (1991). The genus Dombeya (Sterculiaceae) in Continental Africa. National Botanical Garden of Belgium, Meise, Belgium.

Sgorbati, S., Labra, M., Grugni, E., Barcaccia, G., Galasso, G., Boni, U., Mucciarelli, M., Gitterio, S., Iramategui, A. B., Gonzalez, L. V. \& Scannerini, S. (2004). A survey of genetic diversity and reproductive biology of Puya raimondii (Bromeliaceae), the endangered queen of the Andes. Plant Biology 6, 222-230.

SherfF, E. E. (1944). Some additions to our knowledge of the flora of the Hawaiian Islands. American Fournal of Botany 31, 151161.

Skead, C. J. (1967). The sunbirds of Southern Africa. Balkema, Cape Town.

Sмiтh, L. B. \& Downs, R. J. (1974). Pitcairnoideae - Bromeliaceae. Flora Neotropica 14, 1-658. 
Soltis, P. S., Soltis, D. E., Weller, S. G., Sakai, A. K. \& WAGner, W. L. (1996). Molecular phylogenetic analysis of the Hawaiian endemics Schiedea and Alsinidendron (Caryophyllaceae). Systematic Botany 21, 365-379.

Sprengel, G. K. (1793). Das entdeckte Geheimnis der Natur im Bau und in der Befruchtung der Blumen. Friedrich Vieweg, Berlin.

Staub, F. (1988). Evolutionary trends in some Mauritian phanerogams in relation to their pollinators. Proceedings of the Royal Society of Arts and Sciences of Mauritius 5, 7-78.

Stephenson, A. G. (1981). Toxic nectar deters nectar thieves of Catalpa speciosa. American Midland Naturalist 105, 381-383.

Stephenson, A. G. (1982). Iridoid glycosides in the nectar of Catalpa speciosa are unpalatable to nectar thieves. Fournal of Chemical Ecology 8, 1025-1034.

Stevens, P. F. (2001 onwards). Angiosperm Phylogeny Website. Version 6, May 2005. URL: http://www.mobot.org/mobot/ research/apweb/.

Temeles, E. J. \& Kress, W. J. (2003). Adaptation in a planthummingbird association. Science 300, 630-633.

Terry, R. G., Brown, G. K. \& Olmstead, R. G. (1997). Examination of subfamilial phylogeny in Bromeliaceae using comparative sequencing of the plastid locus $n d h \mathrm{~F}$. American Fournal of Botany 84, 664-670.

Thorp, R. W., Briggs, D. L., Estes, J. R. \& Erickson, E. H. (1975). Nectar fluorescence under ultraviolet irradiation. Science 189, 476-478.

Toledo, V. M. (1974). Observations on the relationship between hummingbirds and Erythrina species. Lloydia 37, 482-487.

Tomlinson, P. B. (1986). The botany of mangroves. Cambridge University Press, Cambridge.

Towns, D. R. (2002). Interactions between geckos, honeydew scale insects and host plants revealed on islands in northern New Zealand, following eradication of introduced rats and rabbits. In Turning the tide: the eradication of invasive species (ed. C. R. Veitch and M. N. Clout), pp. 329-335. Invasive Species Specialist Group, IUCN, Gland, Switzerland and Cambridge, UK.

VAHL, M. (1794). Symbolae botanicae, Hauniae (Copenhagen).

van der PIJL, L. (1982). Principles of dispersal in higher plants. Springer Verlag, Berlin.

VAN WyK, B.-E. \& Smith, G. (1996). Guide to the Aloes of South Africa. Briza Publications, Pretoria.

Viljoen, A. M., Van Wyk, B.-E. \& Van Heerden, F. R. (1998). Distribution and chemotaxonomic significance of flavonoids in Aloe (Asphodelaceae). Plant Systematics and Evolution 211, $31-42$.

Vogel, S. (1998). Remarkable nectaries: Structure, ecology, organophyletic perspectives III. Nectar ducts. Flora 193, 113 131.

Wagner, W. L., Weller, S. G. \& Sakai, A. K. (2005). Monograph of Schiedea (Caryophyllaceae - Alsinoideae). Systematic Botany Monographs 72, 1-169.

Walsh, B. M. \& Ноот, S. B. (2001). Phylogenetic relationships of Capsicum (Solanaceae) using DNA sequences from two noncoding regions: The chloroplast atpB-rbcL spacer region and nuclear waxy introns. International Fournal of Plant Sciences 162, 1409-1418.

Wanntorp, L., Kocyan, A. \& Renner, S. S. (2006). Wax plants disentangled: A phylogeny of Hoya (Marsdenieae, Apocynaceae) inferred from nuclear and chloroplast DNA sequences. Molecular Phylogenetics and Evolution 39, 722-733.
Wanntore, L., Kocyan, A., van Donkelaar, R. \& Renner, S. S. (in press). Towards a monophyletic Hoya (Marsdenieae, Apocynaceae): Inferences from the chloroplast trnL region and the rbcL-atpB spacer. Systematic Botany.

Ward, N. M. \& Price, R. A. (2002). Phylogenetic relationships of Marcgraviaceae: Insights from three chloroplast genes. Systematic Botany 27, 149-160.

Weber, A. \& Vogel, S. (1986). The pollination syndrome of Deplanchea tetraphylla (Bignoniaceae). Plant Systematics and Evolution 154, 237-250.

WeIss, M. R. (1991). Floral color changes as cues for pollinators. Nature 354, 227-229.

Weiss, M. R. (1995). Floral color change: A widespread functional convergence. American Fournal of Botany 82, 167-185.

Weller, S. G. \& SaKai, A. K. (1990). The evolution of dicliny in Schiedea (Caryophyllaceae), an endemic Hawaiian genus. Plant Species Biology 5, 83-95.

Weller, S. G., Sakai, A. K. \& Wagner, W. L. (1995). A phylogenetic analysis of Schiedea and Alsinidendron (Caryophyllaceae: Alsinoideae): Implications for the evolution of breeding systems. Systematic Botany 20, 315-337.

Weller, S. G., Sakai, A. K., Wagner, W. L. \& Herbst, D. R. (1990). Evolution of dioecy in Schiedea (Caryophyllaceae: Alsinoideae) in the Hawaiian Islands: Biogeographical and ecological factors. Systematic Botany 15, 266-276.

Weller, S. G., Sakai, A. K., Rankin, A. E., Golonka, A., Kutcher, B. \& Ashby, K. E. (1998). Dioecy and the evolution of pollination systems in Schiedea and Alsinodendron (Caryophyllaceae: Alsinoideae) in the Hawaiian Islands. American Fournal of Botany 85, 1377-1388.

Weller, S. G., Sakai, A. K., Thai, D. A., Tom, J. \& Rankin, A. E. (2005). Inbreeding depression and heterosis in populations of Schiedea viscosa, a highly selfing species. Fournal of Evolutionary Biology 18, 1434-1444.

Wheelwright, N. T. \& Janson, C. H. (1985). Colors of fruit displays of bird-dispersed plants in two tropical forests. American Naturalist 126, 777-799.

Whitaker, A. H. (1987). The roles of lizards in New Zealand plant reproductive strategies. New Zealand Fournal of Botany 25, 315-328.

Wilkinson, D. M., Sherratt, T. N., Phillip, D. M., Wratten, S. D., Dixon, A. F. G. \& Young, A. J. (2002). The adaptive significance of autumn leaf colours. Oikos 99, 402-407.

Willson, M. F. \& Whelan, C. J. (1990). The evolution of fruit color in fleshy-fruited plants. American Naturalist 136, 790-809.

Wilson, P., Castellanos, M. C., Hogue, J. N., Thomson, J. D. \& Armbruster, W. S. (2004). A multivariate search for pollination syndromes among penstemons. Oikos 104, 345-361.

Wolf, L. L. \& GILL, F. B. (1986). Physiological and ecological adaptations of high montane sunbirds and hummingbirds. In High Altitude Tropical Biogeography (ed. F. Vuilleumier and M. Monasterio), pp. 103-119. Oxford University Press, Oxford.

Wooller, R. D. \& Wooller, S. J. (2003). The role of non-flying animals in the pollination of Banksia nutans. Australian fournal of Botany 51, 503-507.

Wyse Jackson, P. S. (1990). Nesocodon mauritianus (Campanulaceae). Kew Magazine 7, 113-117.

Zahavi, A. (1975). Mate selection - A selection for a handicap. Journal of Theoretical Biology 53, 205-214.

ZaHAVI, A. (1977). Cost of honesty (further remarks on handicap principle). Fournal of Theoretical Biology 67, 603-605. 


\section{APPENDIX 1: TABLE REFERENGES}

References for Table 1

\begin{tabular}{|c|c|}
\hline Aloe alooides & $\begin{array}{l}\text { Glen \& Hardy, 1995; S. D. Johnson, unpublished data; B.-E. van Wyk, personal communication; } \\
\text { B. Loison, personal communication. }\end{array}$ \\
\hline A. castanea & Reynolds, 1940; Glen \& Hardy, 1995; Nicolson \& Nepi, 2005; S. D. Johnson, unpublished data. \\
\hline A. vryheidensis & Reynolds, 1940; Dyer, 1941; Glen \& Hardy, 1995; van Wyk \& Smith, 1996; S. D. Johnson, unpublished data. \\
\hline A. spicata & Dyer, 1931; Reynolds, 1940; Glen \& Hardy, 1995; S. D. Johnson, unpublished data. \\
\hline Phormium tenax & $\begin{array}{l}\text { Craig \& Stewart 1988; Isacch, 2002; J. Henning, personal communication; J. L. Craig, personal } \\
\text { communication; P. B. Heenan, personal communication. }\end{array}$ \\
\hline Nesocodon mauritianus & Olesen et al., 1998; Wyse Jackson, 1990. \\
\hline Schiedea lychnoides & Weller \& Sakai, 1990; Weller et al., 1995; Wagner et al., 2005; S. G. Weller, personal communication. \\
\hline S. obovatum & Weller et al., 1995; Wagner et al., 2005; S. G. Weller, personal communication. \\
\hline S. trinerve & Weller et al., 1995; Wagner et al., 2005; S. G. Weller, personal communication. \\
\hline S. viscosum & Weller et al., 1995; Wagner et al., 2005; S. G. Weller, personal communication. \\
\hline Schwartzia brasiliensis & Sazima et al. 1993; Pinheiro et al. 1995; M. Rocca \& M. Sazima, personal communication. \\
\hline Calliandra calothyrsus & Palmer et al., 1994; MacQueen \& Hernández, 1997; Chamberlain, 1998, 2000; Jensen, 2005; Estolas, 2004. \\
\hline Erythrina caffra & Guillarmod et al., 1979; Cheke \& Mann, 2001, Scott-Elliot, 1890. \\
\hline E. humeana & Guillarmod et al., 1979; Cheke \& Mann, 2001. \\
\hline E. zeyheri & Guillarmod et al., 1979. \\
\hline Hoya diversifolia & Hoffmann et al., 2002; D. Liddle, personal communication; R.D. Kloppenburg, personal communication. \\
\hline H. excavata & D. J. Liddle, personal communication; R.D. Kloppenburg, personal communication. \\
\hline H. kerrii & $\begin{array}{l}\text { Hoffmann et al., 2002; D. J. Liddle, personal communication; R. Pettersson, personal communication; } \\
\text { G. Burton, personal communication. }\end{array}$ \\
\hline H. meliflua & Hoffmann et al., 2002; R.D. Kloppenburg, personal communication; D. J. Liddle, personal communication. \\
\hline H. obovata & Hoffmann et al., 2002; D. J. Liddle, personal communication. \\
\hline Melianthus comosus & Scott-Elliot, 1890; H. P. Linder, unpublished data; J. Henning, personal communication. \\
\hline M. dregeanus & Tansley \& Schelpe, 1984; H. P. Linder, unpublished data; J. Henning, personal communication. \\
\hline M. elongatus & H. P. Linder, unpublished data; J. Henning, personal communication. \\
\hline M. gariepinus & $\begin{array}{l}\text { Archer \& Condy, 1997; Tansley \& Schelpe, 1984; H. P. Linder, unpublished data., unpublished data; } \\
\text { J. Henning, personal communication. }\end{array}$ \\
\hline M. insignis & Dyer, 1959; Tansley \& Schelpe, 1984; H. P. Linder, unpublished data. \\
\hline M. major & Scott-Elliot, 1890; H. P. Linder, unpublished data; J. Henning, personal communication. \\
\hline M. pectinatus & Tansley \& Schelpe, 1984; H. P. Linder, unpublished data; J. Henning, personal communication. \\
\hline M. villosus & Dyer, 1952; H. P. Linder, unpublished data; J. Henning, personal communication \\
\hline Deplanchea tetraphylla & Avé, 1984; Weber \& Vogel, 1986; Brown \& Hopkins, 1995; Jackson, 2001. \\
\hline Fernandoa magnifica & Weber \& Vogel, 1986; Beentje, 1994; Diniz, 1988; C. Puff personal communication. \\
\hline Leucosceptrum canum & $\begin{array}{l}\text { Cowan \& Cowan, 1929; Li \& Hedge, 1994; Grierson \& Long, 1999; G.M. Pradhan, } \\
\text { personal communication. }\end{array}$ \\
\hline $\begin{array}{l}\text { Dombeya a. ssp. } \\
\text { acutangula }\end{array}$ & Gigord et al., 1998, 1999; L. Gigord, personal communication. \\
\hline D. a. ssp. palmata & L. Gigord, personal communication. \\
\hline D. a. ssp. rosea & Friedmann, 1987; D. M. Hansen, personal observations. \\
\hline D. cacuminum & Prenner, 2002; Llamas, 2003. \\
\hline D. elegans & Friedmann ,1987; L. Gigord, personal communication. \\
\hline D. kefaensis & Friis \& Bidgood, 1998, 2001. \\
\hline Trochetia blackburniana & Friedmann , 1987; Olesen et al., 1998; D.M. Hansen \& C.B. Müller, unpublished data. \\
\hline T. boutoniana & Friedmann , 1987; Olesen et al. 1998; D.M. Hansen \& C.B. Müller, unpublished data. \\
\hline T. granulata & Friedmann, 1987; D.M. Hansen \& C.B. Müller, unpublished data. \\
\hline T. parviflora & Friedmann, 1987; D.M. Hansen \& C.B. Müller, unpublished data. \\
\hline T. triflora & Friedmann, 1987; D.M. Hansen \& C.B. Müller, unpublished data. \\
\hline T. uniflora & Friedmann, 1987; D.M. Hansen \& C.B. Müller, unpublished data. \\
\hline Lumnitzera littorea & Tomlinson , 1986; H. Skovgaard, personal communication. \\
\hline Banksia grossa & Markey \& Lamont ,1995; George, 1999; B. B. Lamont, personal communication. \\
\hline B. incana & Markey \& Lamont, 1995; George, 1999; B. B. Lamont, personal communication. \\
\hline B. leptophylla & Markey \& Lamont, 1995; George, 1999; B. B. Lamont, personal communication. \\
\hline B. nutans & Markey \& Lamont, 1995; George, 1999; Wooller \& Wooller, 2003; B. B. Lamont, personal communication. \\
\hline B. sphaerocarpa & Lamont, 1980; Markey \& Lamont, 1995; George, 1999; B. B. Lamont, personal communication. \\
\hline B. telmatiaea & Markey \& Lamont, 1995; George, 1999; B. B. Lamont, personal communication. \\
\hline Grevillea robusta & $\begin{array}{l}\text { Skead, 1967; Nicolson, 1993, 1995; Kalinganire, 2000; Makinson, 2000; R. O. Makinson, } \\
\text { personal communication. }\end{array}$ \\
\hline Capsicum baccatum & Eshbaugh, 1970; 1975; W. H. Esbaugh, personal communication. \\
\hline C. pubescens & Eshbaugh, 1975; W. H. Esbaugh, personal communication; A. Boatman, personal communication. \\
\hline
\end{tabular}


References for Table 1: (cont.)

\begin{tabular}{ll}
\hline \hline C. eximium & Eshbaugh, 1975; W. H. Esbaugh, personal communication. \\
Faltomata aspera & Bitter, 1921; T. Mione, unpublished data. \\
7. biflora & Mione et al., 2001; T. Mione, unpublished data. \\
7. herrerae & Mione \& Leiva, 1997; T. Mione, unpublished data. \\
7. paneroi & Mione \& Leiva, 1997; T. Mione, unpublished data. \\
F. umbellata & Mione et al., 1993; T. Mione, unpublished data. \\
7. ventricosa & Mione et al., 1993; T. Mione, unpublished data. \\
7. weberbaueri & T. Mione, unpublished data. \\
7. sp. "contumacencis" & T. Mione, unpublished data. \\
7. sp. "642" & T. Mione, unpublished data. \\
7. sp. "647" & T. Mione, unpublished data. \\
7. sp. "669" & T. Mione, unpublished data. \\
7. sp. "711" & T. Mione, unpublished data.
\end{tabular}

References for Table 2:

\begin{tabular}{|c|c|}
\hline Aloe castanea & Nicolson \& Nepi, 2005. \\
\hline A. vryheidensis & S. D. Johnson et al., unpublished data. \\
\hline Phormium tenax & Craig \& Stewart 1988. \\
\hline Nesocodon mauritianus & Olesen et al.,1998; J. M. Olesen, unpublished data. \\
\hline Schiedea lychnoides & Weller et al., 1998. \\
\hline S. obovata & Weller et al., 1998. \\
\hline S. trinerve & Weller et al., 1998. \\
\hline S. viscosa & Weller et al., 1998. \\
\hline Schwartzia brasiliensis & Sazima et al. 1993; Pinheiro et al. 1995. \\
\hline Calliandra calothyrsus & Jensen, 2005. \\
\hline Erythrina humeana & van Wyk, 1993; S. W. Nicolson, personal communication. \\
\hline E. caffra & van Wyk, 1993; S. W. Nicolson, personal communication. \\
\hline Melianthus comosus & Baker et al., 1998; H. P. Linder, unpublished data; J. Henning, personal communication. \\
\hline M. dregeanus & H. P. Linder, unpublished data; J. Henning, personal communication. \\
\hline M. elongatus & H. P. Linder, unpublished data; J. Henning, personal communication. \\
\hline M. gariepinus & H. P. Linder, unpublished data; J. Henning, personal communication. \\
\hline M. major & Nicolson, 2002; H. P. Linder, unpublished data; J. Henning, personal communication. \\
\hline M. pectinatus & H. P. Linder, unpublished data; J. Henning, personal communication. \\
\hline M. villosus & H. P. Linder, unpublished data; J. Henning, personal communication. \\
\hline Deplanchea tetraphylla & Weber \& Vogel, 1986. \\
\hline Dombeya a. ssp. acutangula & L. Gigord, personal communication. \\
\hline D. angulata ssp. rosea & D. M. Hansen, unpublished data. \\
\hline Trochetia blackburniana & D. M. Hansen \& C.B. Müller, unpublished data. \\
\hline T. boutoniana & D. M. Hansen \& C.B. Müller, unpublished data. \\
\hline T. granulata & D. M. Hansen \& C.B. Müller, unpublished data. \\
\hline T. triflora & D. M. Hansen \& C.B. Müller, unpublished data. \\
\hline T. uniflora & D. M. Hansen \& C.B. Müller, unpublished data. \\
\hline Lumnitzera littorea & H. Skovgaard, personal communication. \\
\hline Banksia leptophylla & Nicolson \& van Wyk, 1998; Markey \& Lamont, 1995. \\
\hline B. sphaerocarpa & Nicolson \& van Wyk, 1998. \\
\hline B. telmatiaea & Nicolson \& van Wyk, 1998. \\
\hline Grevillea robusta & Baker et al., 1998; Kalinganire et al., 2001. \\
\hline Faltomata biflora & Mione et al., 2001. \\
\hline 7. paneroi & J. M. Olesen \& D. M. Hansen, unpublished data. \\
\hline
\end{tabular}

\section{REFERENCES NOT LISTED IN MAIN MANUSCRIPT:}

Macqueen, D. J. \& Hernandéz, H. M., (1997). A revision of Calliandra series Racemosae (Leguminosae: Mimosoideae). Kew Bulletin 52, 1-50.
BeEntje, H. J. (1994). Kenya trees, shrubs \& lianas. National Museums of Kenya, Nairobi, Kenya.

Diniz, M. A. (1988). Bignoniaceae. Flora Zambesiaca Volume 8, Part 3.

Dyer, R. A. (1959). Melianthus insignis. Flowering Plants of Africa 33, Plate 1310. 
Eshbaugh, W. H. (1970). A biosystematic and evolutionary study of Capsicum baccatum (Solanaceae). Brittonia 22, 31-43.

Eshbaugh, W. H. (1975). Genetic and biochemical systematic studies of Chili Peppers (Capsicum - Solanaceae). Bulletin of the Torrey Botanical Club 102, 396-403.

FriIs, I. \& Bidgood, S. (2001). Additional observations on Dombeya kefaensis (Sterculiaceae) and the diversity of Dombeya in SW. Ethiopia. Nordic Journal of Botany 21, 337-340.

Grierson, A. J. C. \& Long, D. G. (1999). Flora of Bhutan. Lamiaceae. Royal Botanical Garden Edinburgh \& Royal Government of Bhutan.

Hoffmann, G., van Donkelaar, R. \& Albers, F. (2002). Hoya. In Illustrated handbook of succulent plants. Asclepiadaceae (ed. F. Albers and U. Meve), pp. 146-158. Springer Verlag, Berlin.

IsACch, J. P. (2002). Nectarivorous feeding by Shiny Cowbirds: A complex feeding innovation. Wilson Bulletin 114, 412-414.
Mione, T., Anderson, G. J. \& Nee, M. (1993). Faltomata I: circumscription, description, and new combinations for five South American species (Solaneae, Solanaceae). Brittonia 45, 138-145.

Mione, T. \& Leiva, G. S. (1997). A new Peruvian species of Faltomata (Solanaceae) with blood-red floral nectar. Rhodora 99, 283-286.

Nicolson, S. W. (2002). Pollination by passerine birds: why are the nectars so dilute? Comparative Biochemistry and Physiology Part B 131, 645-652.

Tansley, S. A. \& Schelpe, E. A. C. L. E. (1984). Melianthaceae. Bothalia 15, 143-145.

VAN WYK, B.-E. 1993. Nectar sugar composition in Southern African Papilionoideae (Fabaceae). Biochemical Systematics \& Ecology 21, 271-277. 